\title{
Glazed sgraffito ware from Torre Alemanna (Foggia, fifteenth to sixteenth century A.D.): technological aspects of a local production
}

\author{
Fioretti Giovanna ${ }^{1}$ (D) Eramo Giacomo ${ }^{1}$ (D) $\cdot$ Monno Alessandro $^{1}$ (D) $\cdot$ Busto Austacio $^{2} \cdot$ Laviano Rocco $^{1}$ (D)
}

Received: 20 September 2021 / Accepted: 27 December 2021 / Published online: 25 January 2022

(c) The Author(s) 2022

\begin{abstract}
The archaeometric investigation of 46 potsherds of "Torre Alemanna type" pottery aimed to define a compositional reference group and to understand the technological characteristics of its production. Principal component analysis applied to bulk chemical data (XRF) of the ceramic body showed a strong compositional homogeneity. Their comparison with local clays and 6 fragments of bricks sampled from the ceramic kiln, on the one hand, revealed the use of alluvial clays as raw material and, on the other hand, proved their fractionation for the production of pottery. The mineralogical assemblages detected by X-ray powder diffraction analysis inferred maximum firing temperatures between 750 and $1000{ }^{\circ} \mathrm{C}$ for the ceramic body. Polarising optical microscopy and scanning electron microscopy with energy dispersive spectroscopy (SEM-EDS) investigations on coating revealed the presence of quartz-rich white engobe covered with a high lead transparent glaze. The polychromatic decoration was analysed by colorimetry and EDS to compare the colour characteristics through all the potsherds. A temperature range between 780 and $950{ }^{\circ} \mathrm{C}$ of liquidus temperatures was inferred from the ternary phase diagram of $\mathrm{PbO}-\mathrm{Al}_{2} \mathrm{O}_{3}-\mathrm{SiO}_{2}$ system. Overlap of temperature ranges for sintering of the ceramic body and maturing glaze points to a single firing of the Torre Alemanna type ware. The results obtained define the reference compositional group and technology of the Torre Alemanna type ware, already attested in several archaeological contexts of southern Italy, and showed a technological continuity with the past about the use of local carbonate-rich clays to produce fine pottery.
\end{abstract}

Keywords Torre Alemanna $\cdot$ Lead glaze $\cdot$ Sgraffito $\cdot$ Colorimetry $\cdot$ Pottery $\cdot$ Apulia

\section{Introduction}

In the 1960s, thanks to the growing number of archaeological investigations on medieval contexts in Italy, the existing typological complexity of glazed ceramics began to come to light (Whitehouse 1978).

Although scholarly attention has mainly focused on the masterpieces of painterly maiolica of the Italian Renaissance (Liverani 1957; Whitehouse 1967; Whitehouse 1978; Goldthwaite 1989; Fabbri et al. 1990; Kingery 1993; Ruffini et al. 2005; Viti et al. 2003; Tite 1991, 2008; Antonelli et al. 2014), a multifaceted stylistic and technological world is emerging on the Italian ceramic production of that period

Eramo Giacomo

giacomo.eramo@uniba.it

1 Dipartimento di Scienze della Terra e Geoambientali, Università degli Studi di Bari Aldo Moro, Bari, Italy

2 ICONEMA S.A.S, Bari, Acquaviva delle Fonti (BA), Italy
(Gardini and Mannoni 1995; Clark et al. 1997; Capelli et al. 2002; Comodi et al. 2004; Laganara Fabiano 2004; Ricci et al. 2005; Capelli and Cabella 2010; De Santis et al. 2012; Heimann et al. 2014).

From the end of the tenth century, there was a resumption of long-distance trade relations which allowed the circulation of coated types of ceramics from the Mediterranean area (Gelichi 1993). The strengthening of trade, banking and specialised manufacturing in the late Middle Ages, especially in central and northern Italy, determined the cultural and technological innovations that led to the definition of fineware maiolica and Medici porcelain (Kingery and Vandiver 1986; Goldthwaite 1989). The import of glazed ceramics from Maghreb and the eastern Mediterranean attests to changes in aesthetic taste and a growing demand for them. Byzantine pottery was a stylistic model for the widespread sgraffito technique in several Italian production centres, as well as Islamic pottery with painted ornaments on a white background and tin-glazed introduced aesthetic and technological aspects, which became typical of Italian maiolica. 
These influences, in a changing socio-economical context, turned some Italian villages from importers of glazed pottery to exporters within a short time span (Whitehouse 1986; Gelichi 1993; Arthur 2007).

In southern Italy, the political conditions for cultural and technological exchange occurred in the multi-ethnic and multi-religious Norman Kingdom of Sicily (1130-1194) (Randazzo 2019). Furthermore, Apulia and Sicily acquired a relevant political and economic role in the late Middle Ages also thanks to the Hohenstaufen dynasty (Buttigieg and Phillips 2016). Apulian protomaiolica (Waagé 1934), as well as other Italian pottery, was found in the Levant from the end of the thirteenth century as traded objects and/or part of the baggage of crusaders and pilgrims (Pringle 1982; Gelichi 1993).

The availability in Apulia of good fine clays, particularly from the Tavoliere plain (Balenzano et al. 1977; Dell'Anna and Laviano 1991; Dondi et al. 1992), and the early human civilisation of its entire territory implied a considerable production and exchange of ceramics, dating back to the Upper Neolithic (Levi et al. 1995; Laviano and Muntoni 2006; Muntoni and Laviano 2011) and developed in Roman times (De Benedetto et al. 2004; Eramo et al. 2004; Gliozzo et al. 2010; Gliozzo et al. 2018) and in the subsequent medieval period (Busto et al 2001; Laganara Fabiano 2004; Favia 2012; Valenzano 2016).

In last decades, several papers have contributed to the knowledge of the production and circulation of glazed ceramics in southern Italy in the medieval and modern ages (Alaimo et al. 2004; dell'Aquila et al. 2006; Catalano et al. 2007; Giannossa et al. 2014; Caggiani et al. 2021).

Noteworthy in this context is the glazed sgraffito (incised) ware produced in the Torre Alemanna complex, where specific forms were produced, such as plates, two-handled cups, bowls and rare jugs. The characteristic decoration was made with a fine carving tool on a white engobe, revealing the light brown background. The decorative motifs are typically geometric and plant like, though some human, zoomorphic and heraldic motifs have also been attested, and colours are yellow-brown, purple and green; glaze drippings are also quite common. A double firing has been hypothesised to sinter the ceramic body and the painted engobe and then to mature the lead glaze (dell'Aquila 2015). Evidence of the diffusion of the Torre Alemanna type has been found in several archaeological contexts in the region (Bari, Canosa di Puglia, Bovino, Gravina, Trani, Laterza, Taranto, Lecce, Soleto) and also in neighbouring Campania (i.e. Montella, Salerno), Molise (Isernia) and Abruzzo (L'Aquila, Sulmona) regions (Salvatore 1980; Carbosiero and Magistrale 1994; Troiano and Verrocchio 2001; dell'Aquila 2015).

Further examples of "sgraffito" ceramics, very similar to the Torre Alemanna type, have been found in other centres in Italy, for example in several sites in Tuscany and in Udine since the fifteenth century, where this type of production was attested in many artisanal kilns (Amato et al. 2006; Ricciardi et al. 2007).

The main objectives of this work are twofold: first, to confirm the archaeological hypothesis of local production and the technology used by the potters and, second, to define a compositional reference group for the Torre Alemanna type, to aid comparisons with other glazed pottery from the Mediterranean area. To achieve these objectives, all the samples were characterised from a mineralogical, petrographic and chemical point of view, and the data obtained with those of local clay sources available in the literature.

\section{The building complex of Torre Alemanna}

After the Teutonic Order's increased prestige following the Fifth Crusade (1218-1221), they obtained papal privileges and various donations to support the knights engaged in the Holy Land. The presence of the Teutonic Knights in Apulia was first established in Brindisi, one of the main ports on the Adriatic coast chosen by the crusaders, followed by Barletta and Bari and Torre Alemanna, located inland, and other minor houses (Buttigieg and Phillips 2016).

Torre Alemanna (Foggia, Apulia) is one of the most important medieval examples of the settlement of the Order of the Teutonic Knights in Southern Italy (thirteenth to the sixteenth century). Situated at the crossroads of two important transhumance routes in the Tavoliere plain, it became an extensive and rich farm. Its geographical position was strategic for producing and selling wheat, wine, oil and other products to ensure supplies and money to the Teutonic Knights engaged in the Holy Land. Until 1789, the fiefdom of Torre Alemanna, which was under the Church rule, was confiscated by the Kingdom of Naples (Busto 2000).

It is a building complex consisting of a square central tower, housing a church dating from the end of the thirteenth century, to which several residential buildings are attached. This central unit is surrounded by defensive walls and service and storage buildings (Busto 2008, 2012; Busto et al. 2015).

The site was abandoned for a long time and archaeological excavation only began in 1999 and covered the entire complex (Busto 2000). The archaeologists discovered and extracted many ceramic artefacts and other movable items from dump pits dated from the thirteenth to the seventeenth century (Busto 2008). The presence of a ceramic kiln, probably used to produce bricks and tiles, suggests a local pottery production. The oldest dump (thirteenth to fourteenth century) was found near the kiln and contained several open forms of glazed sgraffito ware, covered with green or colourless glaze and decorated with red and brown linear motifs. 
The archaeological excavations conducted by the archaeological Authority of the Apulia region in 1999-2000 uncovered and extracted a number of imported maiolica pieces together with a large number of glazed sgraffito potsherds, dating from the fifteenth to the sixteenth century, found in a granary pit in the apartment house of the Abbot, reused as a dump and sealed during building alterations to the structure, dated to 1570 by an inscription. The maiolica pottery was marked with the symbol of Torre Alemanna production, then suggesting local glazed ware production (dell'Aquila 2015). Polychrome glazed pottery was previously unknown and its particular typological characteristics allowed the definition of "Torre Alemanna type" pottery (Busto et al. 2001).

\section{Geological substratum}

The Torre Alemanna building complex (DMS geographical coordinates: $41^{\circ} 11^{\prime} 08^{\prime \prime} \mathrm{N} 15^{\circ} 42^{\prime} 46^{\prime \prime} \mathrm{E}$ ) is located in the Tavoliere di Puglia plain, a vast flat area bordering on the $S$ with the Murgia plateau, on the $\mathrm{W}$ with the "Subappennino Dauno" (outer units of southern Apennine chain) and on the NE with the Gargano promontory. This area is part of the northern sector of the Bradanic foreland (Bradanic trough, Azzaroli et al., 1968), formed following the subduction of the Apulian platform under the Apennine chain (Middle Pliocene-Lower Pleistocene) (Ricchetti et al., 1988; Doglioni et al., 1994, 1996). The geological and geomorphological features of the Tavoliere are the result of two geodynamic phases that occurred from the Pliocene to the Holocene: firstly, the accumulation of transgressive units on the Mesozoic limestone basement, from shallow marine carbonate deposits (Calcarenite di Gravina Fm) to the silty-clayey hemipelagic deposits of the Argille subappennine Fm (Pieri et al., 1996; Tropeano et al., 2002), and secondly, the combination of glacio-eustatic sea-level fluctuations and polyphase uplift $(0.1-0.5 \mathrm{~mm} /$ year), with the deposition of shallow marine and continental deposits on the Argille subappennine Fm, forming the Tavoliere di Puglia supersynthem from the Lower Pleistocene (Jacobacci et al., 1967; Merla et al., 1969; Caldara and Pennetta, 1991, 1993; De Santis et al., 2010; Moretti et al., 2010; Caldara et al. 2011; Gallicchio et al., 2014).

The available clayey raw materials in the Torre Alemanna area (Fig. 1) are essentially represented by the carbonate-rich Argille subappennine Fm (Lower Pleistocene) and alluvial deposits (Upper Pleistocene-Holocene) outcropping along river beds (Eramo et al. 2004; Gliozzo et al. 2005, 2018).

\section{Sampling and analytical methods}

All 46 potsherds analysed here were fragments of glazed sgraffito plates excavated from a dump in the apartment house of the Abbot, all datable from the late fifteenth to the sixteenth century (Table 1). The thickness of the walls is between 6 and $8 \mathrm{~mm}$, while the maximum diameter of plates is $33 \mathrm{~cm}$. A selection of the typical shapes and decorations is shown in Figures 2 and 3. Other 6 samples from the bricks (TAL1-6) of the ceramic kiln (Fig. 4), found in a building

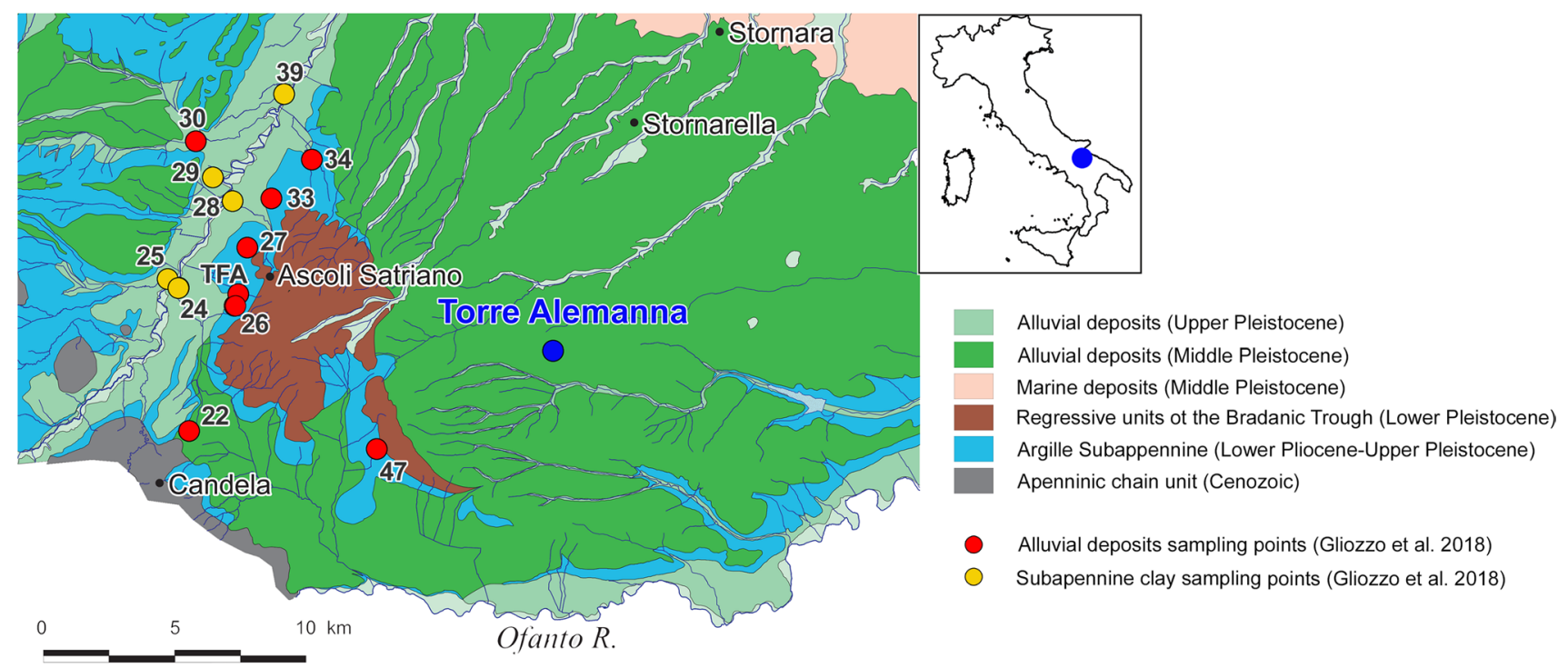

Fig. 1 Geological map of the area of Torre Alemanna (De Santis et al. 2013, modified). Sampling points of alluvial clays (47: Ofanto valley; 22: Candela; 26, TFA: Carapelle valley; 27: clay quarry, Ascoli Satriano; 33: Faragola archaeological site; 34: Cappello Tosto;
30: Palazzo di Ascoli) and Argille subappennine Fm (24, 25, 28, 29, 39: Carapelle valley) considered reference for local clays (Gliozzo et al. 2018) 
Table 1 The archaeological features of the analysed samples, including position in the vessel, thickness and colour coordinates (CIEL*a*b*) of the ceramic body. In parenthesis, the letter corresponds to the decorative motifs represented in Fig. 3. Abbreviations: TAt $=$

Torre Alemanna type; ND = not determined

\begin{tabular}{|c|c|c|c|c|c|c|}
\hline \multirow[t]{2}{*}{ Sample } & \multirow[t]{2}{*}{ Typology } & \multirow[t]{2}{*}{ Position } & \multirow{2}{*}{$\begin{array}{l}\text { Thickness } \\
(\mathrm{mm})\end{array}$} & \multicolumn{3}{|c|}{ Body colour } \\
\hline & & & & $\mathrm{L}^{*}$ & $a^{*}$ & $\mathrm{~b}^{*}$ \\
\hline TA04 & TAt & Rim (g) & 6 & 70.9 & 10.2 & 20.1 \\
\hline TA05 & TAt & Bottom (b) & 5 & 67.3 & 10.5 & 31.5 \\
\hline TA06 & TAt & $\operatorname{Rim}(d)$ & 6 & 62.4 & 12.5 & 34.4 \\
\hline TA07 & TAt & Wall (f) & 7 & 65.2 & 10.7 & 20.0 \\
\hline TA08 & TAt & $\operatorname{Rim}(d)$ & 6 & 61.7 & 19.4 & 26.1 \\
\hline TA09 & TAt & $\operatorname{Rim}(\mathrm{d}, \mathrm{h})$ & 9 & 71.3 & 8.0 & 22.8 \\
\hline TA10 & TAt & $\operatorname{Rim}(d)$ & 10 & 72.1 & 10.2 & 20.2 \\
\hline TA11 & TAt & $\operatorname{Rim}(d)$ & 7 & 72.6 & 12.4 & 16.9 \\
\hline TA12 & TAt & Wall (h) & 6 & 60.9 & 9.0 & 20.0 \\
\hline TA13 & TAt & Rim (ND) & 6 & 63.1 & 9.2 & 21.9 \\
\hline TA14 & TAt & Bottom $(\mathrm{d}, \mathrm{h})$ & 6 & 71.6 & 8.5 & 20.8 \\
\hline TA15 & TAt & $\operatorname{Rim}(k)$ & 5 & 68.6 & 10.4 & 19.1 \\
\hline TA16 & TAt & Wall (h) & 6 & 62.7 & 10.6 & 21.9 \\
\hline TA17 & TAt & Wall (h) & 6 & 69.9 & 11.1 & 24.1 \\
\hline TA18 & TAt & Wall (h) & 6 & 61.8 & 16.0 & 30.9 \\
\hline TA19 & TAt & $\operatorname{Rim}(\mathrm{d}, \mathrm{h})$ & 7 & 62.5 & 16.8 & 20.0 \\
\hline TA20 & TAt & $\operatorname{Rim}(d)$ & 7 & 63.4 & 19.4 & 26.2 \\
\hline TA21 & TAt & $\operatorname{Rim}(d)$ & 6 & 65.2 & 12.1 & 20.0 \\
\hline TA22 & TAt & $\operatorname{Rim}(\mathrm{ND})$ & 4 & 60.3 & 4.3 & 11.5 \\
\hline TA23 & TAt & Wall (d) & 6 & 61.1 & 19.5 & 26.1 \\
\hline TA24 & TAt & $\operatorname{Rim}(d)$ & 7 & 62.1 & 8.2 & 15.0 \\
\hline TA25 & TAt & Rim (ND) & 7 & 30.8 & 8.1 & 30.0 \\
\hline TA26 & TAt & Rim (ND) & 6 & 64.8 & 10.8 & 20.0 \\
\hline TA27 & TAt & Rim (ND) & 4 & 61.9 & 10.3 & 21.9 \\
\hline TA28 & TAt & Rim (ND) & 6 & 63.0 & 10.8 & 18.7 \\
\hline TA29 & TAt & Bottom (c) & 6 & 41.2 & 15.0 & 17.6 \\
\hline TA30 & TAt & Bottom (a) & 6 & 65.8 & 16.0 & 30.9 \\
\hline TA31 & TAt & Bottom (ND) & 9 & 71.4 & 3.9 & 11.5 \\
\hline TA32 & TAt & Wall (e) & 6 & 64.2 & 12.8 & 17.0 \\
\hline TA33 & TAt & Rim (ND) & 7 & 65.2 & 19.4 & 26.7 \\
\hline TA34 & TAt & Bottom (ND) & 6 & 66.8 & 10.7 & 20.9 \\
\hline TA35 & TAt & Rim (ND) & 7 & 30.8 & 9.9 & 14.6 \\
\hline TA36 & TAt & Bottom (ND) & 7 & 62.9 & 8.5 & 22.5 \\
\hline TA37 & TAt & Rim (1) & 5 & 63.1 & 9.8 & 12.7 \\
\hline TA38 & TAt & Rim (ND) & 5 & 64.1 & 9.5 & 22.5 \\
\hline TA39 & TAt & Rim (ND) & 6 & 64.6 & 16.0 & 30.9 \\
\hline TA40 & TAt & $\operatorname{Rim}(N D)$ & 6 & 51.4 & 15.1 & 27.8 \\
\hline TA41 & TAt & Rim (ND) & 8 & 62.9 & 17.1 & 26.9 \\
\hline TA42 & TAt & $\operatorname{Rim}(N D)$ & 7 & 60.8 & 19.4 & 26.1 \\
\hline TA44 & TAt & $\operatorname{Rim}(j)$ & 6 & 41.2 & 15.0 & 17.6 \\
\hline TA45 & TAt & Wall (ND) & 8 & 62.8 & 11.0 & 20.3 \\
\hline TA46 & TAt & Rim (ND) & 9 & 59.2 & 10.4 & 17.9 \\
\hline TA47 & TAt & $\operatorname{Rim}(h, i)$ & 7 & 61.5 & 12.8 & 18.7 \\
\hline TA48 & TAt & Rim (i) & 6 & 41.2 & 15.0 & 17.7 \\
\hline TA49 & TAt & Rim (i) & 5 & 62.7 & 16.0 & 30.9 \\
\hline TA50 & TAt & Rim (i) & 6 & 63.6 & 19.4 & 26.1 \\
\hline TAL01 & Brick & Firebox, wall (W sector, inside) & 43 & 34.4 & 11.7 & 17.3 \\
\hline TAL02 & Brick & Firebox, wall (W sector, inside) & 49 & 38.9 & 15.5 & 18.5 \\
\hline TAL03 & Brick & Firebox, domed roof (W sector, inside) & 40 & 45.8 & 12.4 & 18.2 \\
\hline
\end{tabular}


Table 1 (continued)

\begin{tabular}{lllllll}
\hline Sample & Typology & Position & $\begin{array}{l}\text { Thickness } \\
(\mathrm{mm})\end{array}$ & \multicolumn{3}{l}{ Body colour } \\
\cline { 5 - 7 } & & & & $\mathrm{L}^{*}$ & $\mathrm{a}^{*}$ & $\mathrm{~b}^{*}$ \\
\hline TAL04 & Brick & Firebox, domed roof (W sector, outside) & 42 & 30.5 & 14.4 & 24.6 \\
TAL05 & Brick & Firebox, domed roof (E sector, inside) & 37 & 28.8 & 16.7 & 28.6 \\
TAL06 & Brick & Firebox, domed roof (E sector, outside) & 38 & 35.4 & 14.2 & 21.3 \\
\hline
\end{tabular}

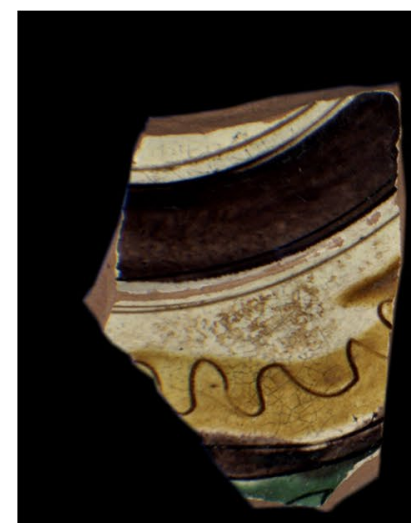

TA45

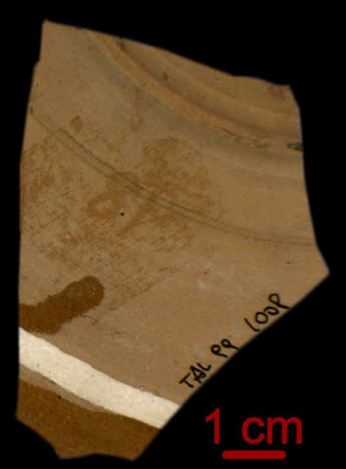

.

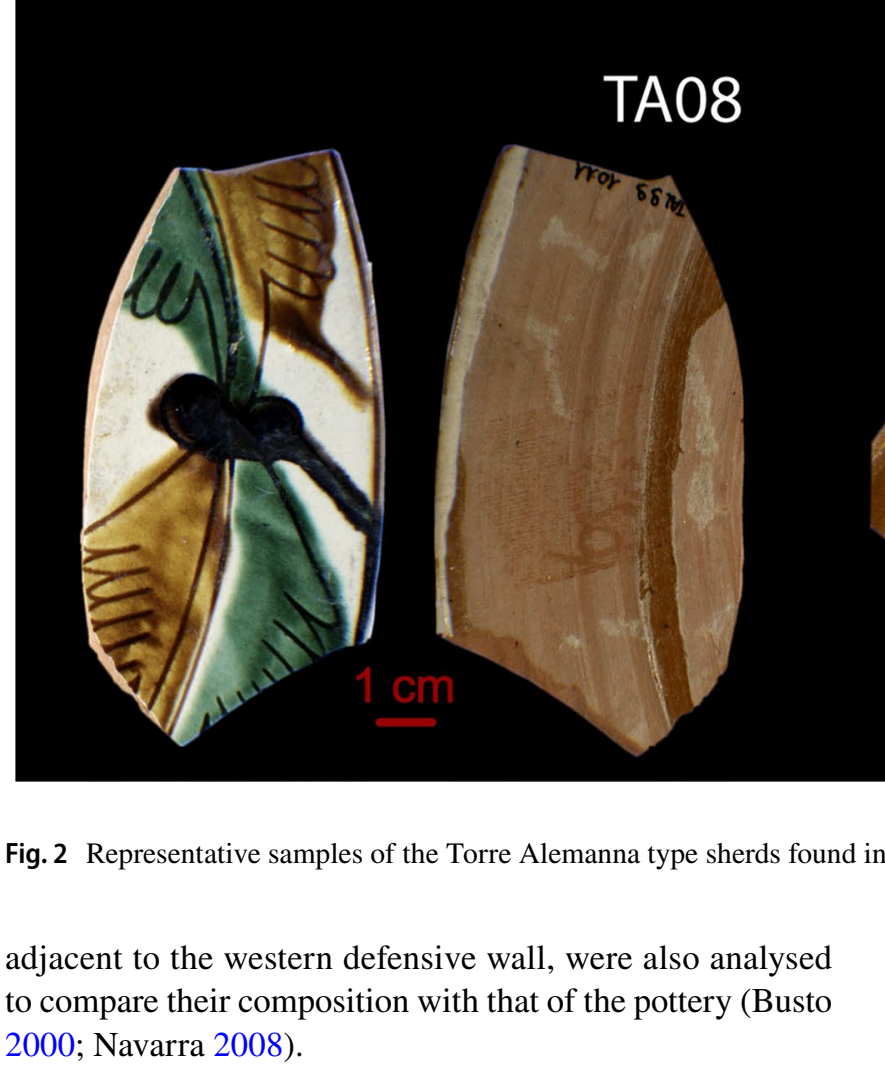

\section{Colorimetry}

Colorimetric analyses of the glaze were carried out with a Konica-Minolta CM-2600d spectrophotometer obtaining data in the CIEL*a*b* colour space. One hundred

and nineteen colour measurements were taken using the standard illuminant D65 (Xe flashlight source, UV included) over a measurement area of $\varnothing=6 \mathrm{~mm}$ (observer angle $=10^{\circ}$ ). Each measurement was acquired considering the specular component included (SCI) and was replicated three times to obtain the mean value. The measurements were performed on planar portions of the surface with homogeneous colour. A surface cleaning with $2 \% \mathrm{HCl}$ water solution was conducted before colour measurements. 
Fig. 3 Drawings of the decorative motifs identified on the analysed potsherds
Bottom
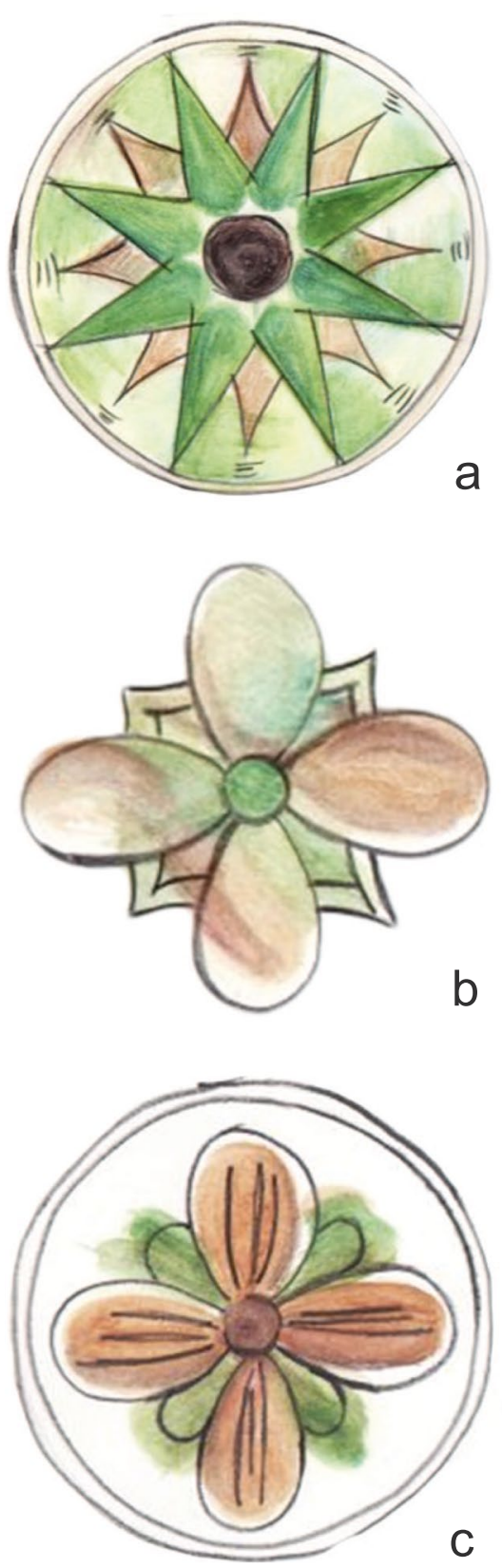

Rim/wall
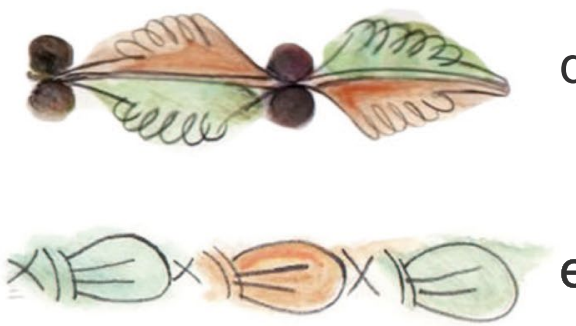

e

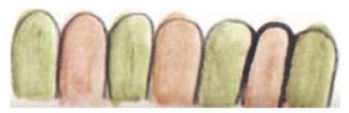

f

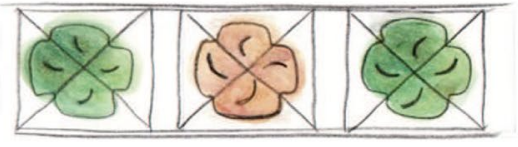

g

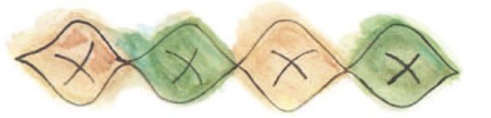

$\mathrm{h}$
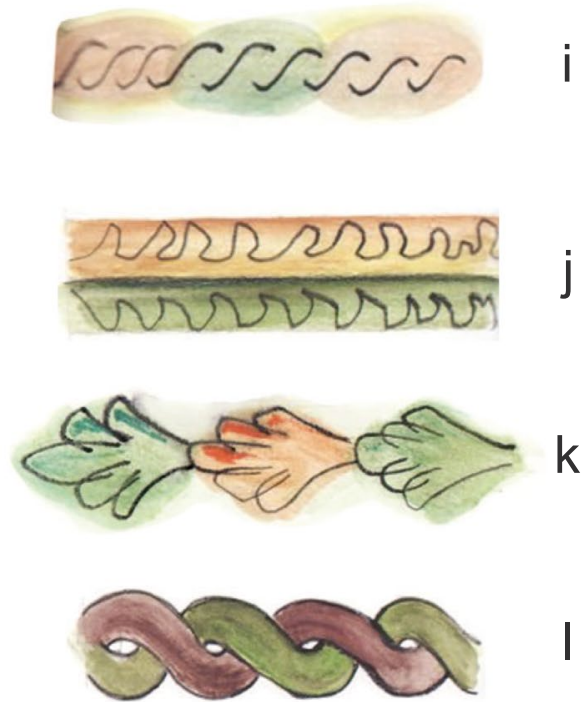

\section{Polarising optical microscope (POM)}

Pottery fabric analysis was conducted on thin sections under a Carl Zeiss Axioskop 40 Pol polarising microscope (POM). The petrographic description included the compositional and textural aspects of the ceramic body, as well as those of the engobe and glaze, when present. The abundance of non-plastic inclusions (NPIs) and macro-porosity was obtained by visual estimation using comparison charts (Matthew et al. 1991), considering $15 \mu \mathrm{m}$ as threshold between NPIs and matrix (Maggetti 1982). Primary (prefiring) and secondary (firing-induced) porosities were recognised under the POM. Following Eramo and Mangone (2019) and Eramo (2020), several aspects were recognised: birefringence, oxidation patterns, compositional features and clay pellets presence for the matrix; NPIs features in terms of nature, volume percentage and grain-size distribution for the ceramic body and the engobe; and vesiculation, presence of relic phases and alteration for the glaze. 

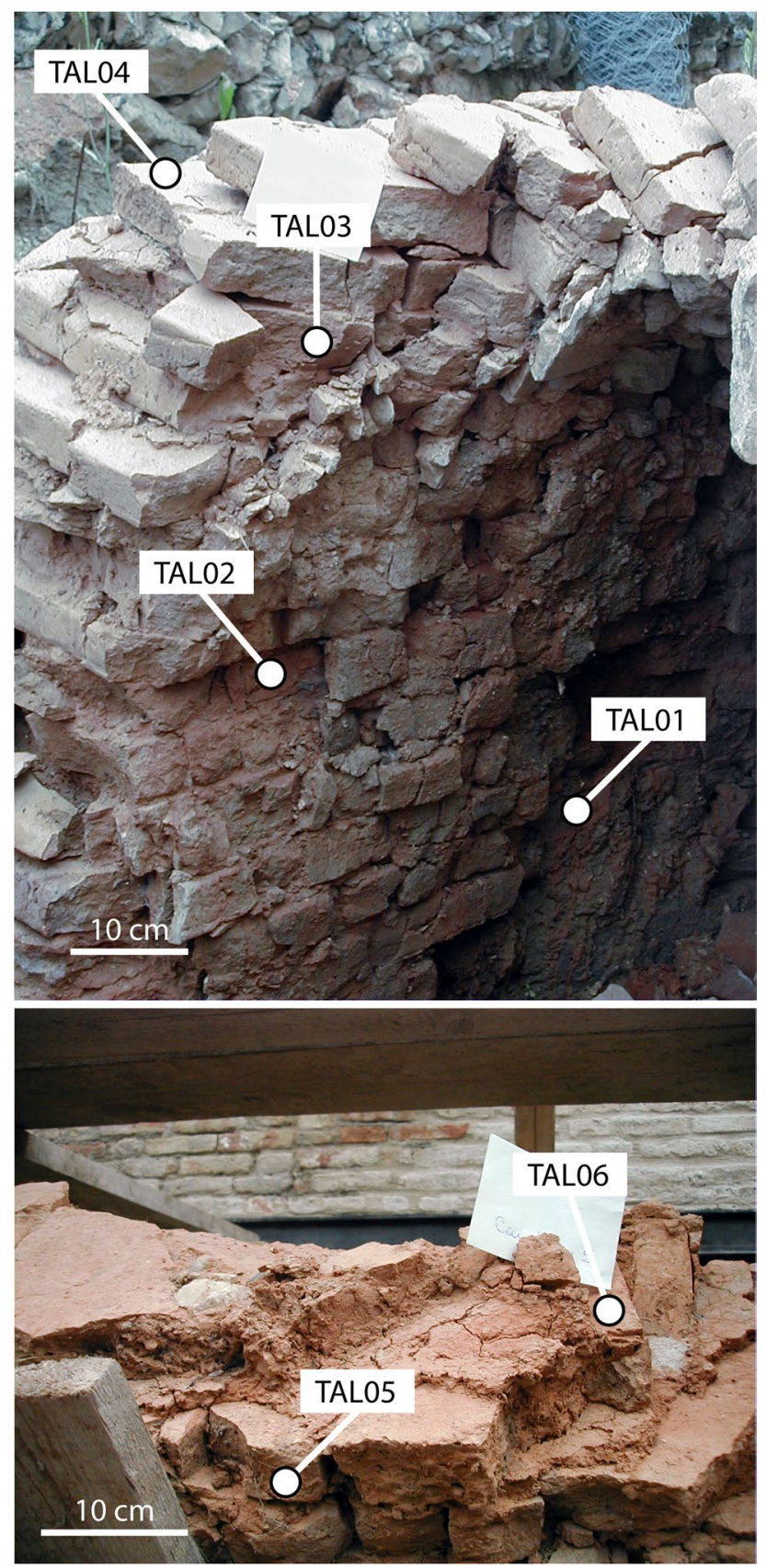

Fig. 4 Position of the brick specimens sampled form the wall and roof of the ceramic kiln of Torre Alemanna

\section{X-ray powder diffraction (XRPD)}

X-ray powder diffraction analysis (XRPD) was performed by using a Philips X'Pert Pro X-Ray diffractometer under the following working conditions: $\mathrm{Cu}-\mathrm{Ka} \mathrm{Ni}$-filtered radiation, $40 \mathrm{kV}, 40 \mathrm{~mA}$, divergence slit $1^{\circ}$, anti-scatter slit $0.5^{\circ}$, receiving slit $0.2 \mathrm{~mm}$, step angle of $0.02^{\circ}, 2 \theta$ from 2 to $65^{\circ}$, measuring time $1 \mathrm{~s}$ per step. The diffraction peaks of the XRPD spectra were identified by comparison with the Joint
Committee on Powder Diffraction International Centre for Diffraction Data (JCPDS-ICDD); diffraction chart and crystalline phases were detected.

Coatings and encrustations were mechanically removed from the analysed portions. The clean ceramic bodies were pulverised for $8 \mathrm{~min}$ at a frequency of $10 \mathrm{~Hz}$ in the vibratory ball mill Retsch MM 400, equipped with two WC grinding jars.

The degree of sintering ranges between "low-medium" and "medium-high", according to their mineralogical characteristics and birefringence observed under POM. The range of the equivalent firing temperatures (EFTs, after Tite 1995) was estimated according to the thermal stability (disappearance/appearance) of the mineral phases and their peak ratios as detected by XRPD.

\section{X-ray fluorescence (XRF)}

Four grams of the sample powder (see above) were bound with Elvacite ${ }^{\circledR}$ dissolved in acetone and then dried for pill preparation. Pills were obtained by pressing the dry powder in small aluminium cups under a hydraulic press.

The determination of major and minor oxides $\mathrm{SiO}_{2}$, $\mathrm{TiO}_{2}, \mathrm{Al}_{2} \mathrm{O}_{3}, \mathrm{Fe}_{2} \mathrm{O}_{3}, \mathrm{MnO}, \mathrm{MgO}, \mathrm{CaO}, \mathrm{Na}_{2} \mathrm{O}, \mathrm{K}_{2} \mathrm{O}$ and $\mathrm{P}_{2} \mathrm{O}_{5}$ ) and trace elements ( $\left.\mathrm{Rb}, \mathrm{Sr}, \mathrm{Y}, \mathrm{Zr}, \mathrm{Nb}\right)$ concentration was performed using an automatic spectrometer Panalytical AXIOS-Advanced, equipped with the X-ray tube X SST$\operatorname{mAX}$ ( $\mathrm{Rh}$ anode), following the analytical techniques outlined by Franzini et al. $(1972,1975)$ and Leoni and Saitta (1976a, b) and checking the accuracy with two international standards (AGV-1 of USGS-USA and NIMGof NIM-South Africa). Detection limit for major elements oxides was $0.01 \%$ wt. Loss on ignition (LOI) was determined by heating the samples at $1000{ }^{\circ} \mathrm{C}$ for $12 \mathrm{~h}$.

\section{Scanning electron microscopy (SEM-EDS)}

The scanning electron microscope (SEM) used in this research was a 50XVP LEO, operated at $15 \mathrm{kV}, 500 \mathrm{pA}$ probe current, about 25,000 cps output as average count rate on the whole spectrum, counting time $50 \mathrm{~s}$ and $8.5 \mathrm{~mm}$ as working distance. Energy dispersive spectrometric (EDS) microanalyses were conducted using an X-Max N (80 $\mathrm{mm}^{2}$ ) SDD detector and AZtec software (Oxford Instruments) for X-ray maps and the correction of X-ray intensity was performed following Pouchou and Pichoir (1991). Different Micro-Analysis Consultants Ltd. (U.K.) mineral standards were used to check the accuracy of the analytical data. For the SEM investigation, 7 samples (TA09, TA29, TA38, TA42, TA44, TA45 and TA46) were selected after the macro- and microscopic analyses as representative of glaze colour variability and petrographic characteristics of 
the coatings. Their thin sections were coated with graphite for SEM investigations.

\section{Statistical analysis}

Chemical data of TA (potsherds), obtained from XRF analysis, were compared with those of TAL (bricks) and with local clay sediments (Eramo et al. 2004, 2012, 2013; Gliozzo et al. 2018). To make these data, obtained in different laboratories, comparable, the concentrations of the major and minor oxides and trace elements were normalised to $\mathrm{SiO}_{2}$ values. Multivariate statistical analysis of the chemical data was considered to verify the existence of correlations among variables of each dataset. Therefore, principal component analysis (PCA) was applied, after standardisation of normalised data to ensure the normal distribution and the same variance $(\mu=0 ; \sigma=1)$ (Davis 1986, p. 517). The software Past 3 (Hammer et al. 2001) was used for the statistical processing and drawing of petrographic and chemical data.

\section{Results}

\section{Macroscopic description}

All the glazed potsherds belonged to open-shaped vessels, and on the concave surface, they showed signs of engraving that followed decorative motifs, from a geometric and vegetal repertoire, and yellow, brown, green and purple pictorial decorations, which usually followed the incised decorative motifs (sgraffito). Figure 3 shows the decorative motifs identified on the analysed potsherds. A thin layer of glaze was applied to all ceramic samples. Some appeared deteriorated due to devitrification and/or surface encrustation. The uncoated portions of the ceramic body showed signs of wheel throwing (Fig. 2). The thickness of fragments was 4-10 $\mathrm{mm}$ for rims, $6-8 \mathrm{~mm}$ for walls and 5-7 $\mathrm{mm}$ for bottoms. Some drippings due to the application of the engobe and glaze are recognisable on the back of the brim of the plates (Fig. 2). On the surface of some samples, black or grey burn shades were well visible, whereas no tripod marks were detected.

\section{Colour analysis}

The macroscopic observation was supported by colorimetric analysis of the ceramic body and glaze. Results, expressed in CIEL*a*b* chromatic space for each colour, are reported in Tables 1 and 2 and plotted in Fig. 5. Although colorimetric data of ceramic body referred to the predominant colour, in most of the samples of Torre Alemanna type $a^{*}$ and $b^{*}$ values gathered along the red range values and more sputtered along the yellow range values. Some samples showed a colour more similar to that of the bricks (Fig. 5a). Referring to purple and green areas, data indicated a clear homogeneity of $a^{*}$ and $b^{*}$ values, as well as for colourless glaze on white engobe. In the yellow-brown cases, it appeared more dispersed along the yellow range values (Fig. 5b).

\section{POM}

Under the optical microscope, the 52 ceramic bodies showed 3 types of fabric. Full oxidation pattern $(\mathrm{Str}=\mathrm{O})$ is common to all the fabrics. A detailed report of the petrographic features is shown in Table 3.

The KQ_k fabric was observed in 39 potsherd samples (Fig. 6a) and 3 brick samples (Fig. 7a). They contained mainly about $20-30 \%$ vol of NPIs, which mostly included calcite and quartz, and in addition plagioclase, K-feldspar, muscovite, iron aggregates and polycrystalline quartz only in a few samples. The grain-size distribution was unimodal, with a mode of 32-63 $\mu \mathrm{m}$ for potsherds and $63-125 \mu \mathrm{m}$ for bricks, although larger inclusions (up to $1000 \mu \mathrm{m}$ ) were observed. Matrix is carbonate-rich. The primary porosity ranges between 10 and $20 \%$ vol.

Fabric KQKa_k (Fig. 6b) is peculiar of 5 potsherd samples. The NPIs are about $20-30 \%$ vol in volume and were calcite, quartz and carbonate aggregates, with subordinate plagioclase, K-feldspar, muscovite and iron aggregates. Polycrystalline quartz was detected only in TA50. Unimodal distribution of NPIs has generally $16-32$ or $32-63 \mu \mathrm{m}$ as mode, even if fragments up to $800 \mu \mathrm{m}$ were also identified. Matrix appeared marly. Primary porosity is about $10 \%$ vol.

Two samples of dishes (Fig. 6c) and 2 of bricks (Fig. 7b) show KQKa_kcp fabric. In those samples, the NPIs have unimodal distribution which was composed of calcite, quartz, carbonate fragments and following plagioclase, K-feldspar, muscovite and iron aggregates. NPIs reached size of $1400 \mu \mathrm{m}$. Matrix was marly and rich in clay pellets. Porosity was about $10-15 \%$ vol. In general, calcite grains show thermal alteration due to firing.

Petrographic investigation under POM identified the overlapping of white engobe and glaze layer on the ceramic body. The boundary between the engobe and the ceramic body is visible but not sharp (Figs. 6, 8). For all the observed samples, the engobe showed common characteristics-thickness of 100-200 $\mu \mathrm{m}$, presence of monocrystalline quartz and minor feldspars with unimodal distribution (mainly 16-32 $\mu \mathrm{m}$ ) and prevalent illite in the matrix - as evidenced by the K map in Fig. 8.

Lead glaze ("SEM-EDS" section) thickness ranges from 80 to $200 \mu \mathrm{m}$ and is separated by a clear boundary from the engobe, except for TA04, TA34 and TA42, with a merging boundary. In most of the cases, traces of quartz relics and bubbles were observed (Table 3 ). 
Table 2 Colour coordinates (CIEL*a*b*) of the polychromatic decorations of the coating

\begin{tabular}{|c|c|c|c|c|c|c|c|c|c|c|c|c|c|c|c|}
\hline \multicolumn{4}{|c|}{ White (engobe) } & \multicolumn{4}{|c|}{ Yellow-brown } & \multicolumn{4}{|l|}{ Green } & \multicolumn{4}{|l|}{ Purple } \\
\hline Sample & $\mathrm{L}^{*}$ & $a^{*}$ & $\mathrm{~b}^{*}$ & Sample & $\mathrm{L}^{*}$ & $\mathrm{a}^{*}$ & $b^{*}$ & Sample & $\mathrm{L}^{*}$ & $a^{*}$ & $b^{*}$ & Sample & $\mathrm{L}^{*}$ & $a^{*}$ & $\mathrm{~b}^{*}$ \\
\hline TA04 & 80.2 & -0.3 & 16.9 & TA04 & 63.2 & 10.4 & 54.4 & TA04 & 37.0 & -12.9 & 9.9 & TA04 & 26.8 & 6.1 & 3.2 \\
\hline TA04 bis & 81.4 & -2.7 & 15.4 & TA05 & 55.5 & 11.2 & 40.6 & TA05 & 53.2 & -19.5 & 16.8 & TA06 & 29.8 & 2.8 & 1.3 \\
\hline TA05 & 77.2 & 2.8 & 15.6 & TA06 & 47.8 & 12.4 & 30.5 & TA06 & 41.8 & -13.9 & 13.2 & TA08 & 27.3 & 1.0 & -1.6 \\
\hline TA06 & 81.4 & -0.4 & 21.9 & TA07 & 62.9 & 4.5 & 42.9 & TA07 & 42.8 & -18.3 & 16.2 & TA09 & 24.5 & 2.7 & -3.6 \\
\hline TA06 bis & 53.4 & -1.1 & 14.5 & TA08 & 54.8 & 17.0 & 50.5 & TA08 & 47.6 & -18.8 & 14.6 & TA10 & 32.3 & 2.2 & 4.8 \\
\hline TA08 & 80.7 & 0.0 & 13.7 & TA09 & 55.2 & 19.2 & 55.2 & TA09 & 59.5 & -16.8 & 17.7 & TA11 & 30.4 & 0.1 & -0.3 \\
\hline TA08 bis & 82.4 & -0.5 & 15.3 & TA10 & 51.9 & 21.1 & 46.3 & TA10 & 59.2 & -14.0 & 20.2 & TA12 & 31.1 & 4.9 & 4.9 \\
\hline TA09 & 79.2 & 3.8 & 17.8 & TA11 & 53.5 & 17.4 & 45.9 & TA11 & 47.9 & -15.7 & 16.8 & TA14 & 32.6 & 5.9 & 2.9 \\
\hline TA10 & 80.6 & 0.1 & 20.5 & TA12 & 43.7 & 5.4 & 17.5 & TA12 & 40.3 & -18.0 & 10.2 & TA14 bis & 32.8 & 4.4 & 1.1 \\
\hline TA11 & 79.1 & 0.8 & 17.6 & TA14 & 59.7 & 14.8 & 52.5 & TA13 & 48.2 & -16.8 & 22.0 & TA16 & 16.2 & 0.3 & -0.3 \\
\hline TA12 & 73.1 & 2.2 & 18.8 & TA15 & 61.7 & 12.6 & 58.5 & TA15 & 41.7 & -19.2 & 15.2 & TA21 & 40.2 & 3.1 & 9.5 \\
\hline TA13 & 79.8 & 1.0 & 16.8 & TA16 & 53.6 & 16.2 & 43.0 & TA16 & 46.2 & -15.0 & 12.3 & TA23 & 41.1 & 9.7 & 9.1 \\
\hline TA14 & 82.7 & -1.8 & 22.2 & TA19 & 54.3 & 10.2 & 30.5 & TA19 & 51.4 & -2.0 & 20.5 & TA24 & 39.5 & 5.1 & 5.1 \\
\hline TA14 bis & 78.7 & 0.7 & 19.4 & TA21 & 65.8 & 9.0 & 25.4 & TA19 bis & 49.8 & -6.2 & 21.0 & TA25 & 34.9 & 4.5 & 1.6 \\
\hline TA15 & 84.9 & 0.4 & 16.4 & TA23 & 60.5 & 14.8 & 47.4 & TA21 & 51.2 & -11.0 & 17.4 & TA26 & 37.7 & 1.2 & 6.0 \\
\hline TA16 & 76.9 & 1.1 & 17.5 & TA25 & 55.0 & 16.5 & 48.2 & TA23 & 54.6 & -5.3 & 18.3 & TA28 & 33.7 & 2.4 & 5.1 \\
\hline TA20 & 72.7 & 5.3 & 21.5 & TA26 & 55.0 & 9.6 & 27.7 & TA25 & 52.2 & -19.3 & 17.3 & TA30 & 30.3 & 3.5 & 0.5 \\
\hline TA24 & 79.5 & -2.0 & 22.2 & TA27 & 43.5 & 10.3 & 20.1 & TA26 & 42.0 & -11.8 & 6.8 & TA35 & 38.8 & 16.1 & 17.5 \\
\hline TA25 & 81.3 & 0.3 & 18.1 & TA30 & 68.4 & 3.1 & 31.4 & TA27 & 41.8 & -15.6 & 10.5 & TA41 & 35.2 & 1.8 & 4.5 \\
\hline TA32 & 74.5 & 2.4 & 14.3 & TA32 & 57.9 & 11.2 & 41.2 & TA30 & 56.9 & -18.8 & 18.3 & TA47 & 33.2 & 2.7 & 4.8 \\
\hline TA33 & 72.8 & -0.2 & 12.0 & TA35 & 43.8 & 15.6 & 29.6 & TA30 bis & 31.4 & -5.3 & 3.8 & & & & \\
\hline TA34 & 77.9 & -2.5 & 18.8 & TA41 & 58.6 & 9.1 & 27.8 & TA32 & 67.7 & -13.4 & 7.0 & & & & \\
\hline TA35 & 78.0 & 1.3 & 16.6 & TA44 & 59.1 & 13.4 & 41.1 & TA35 & 44.9 & -11.8 & 12.7 & & & & \\
\hline TA36 & 74.9 & -4.6 & 18.5 & TA47 & 56.3 & 7.4 & 38.0 & TA36 & 40.9 & -13.6 & 14.0 & & & & \\
\hline TA37 & 79.5 & -2.5 & 20.2 & TA48 & 61.1 & 4.4 & 33.2 & TA37 & 36.2 & -6.8 & 9.3 & & & & \\
\hline TA38 & 81.2 & 3.7 & 13.9 & TA49 & 61.3 & 6.9 & 39.8 & TA40 & 47.8 & -8.4 & 15.9 & & & & \\
\hline TA39 & 66.9 & 3.4 & 20.6 & TA50 & 66.5 & 5.6 & 38.0 & TA41 & 37.0 & -6.6 & 4.7 & & & & \\
\hline TA42 & 69.5 & 6.3 & 17.1 & & & & & TA42 & 45.0 & -4.9 & 8.5 & & & & \\
\hline TA47 & 52.4 & 2.8 & 19.2 & & & & & TA44 & 49.5 & -13.7 & 12.1 & & & & \\
\hline TA48 & 79.0 & -1.8 & 12.8 & & & & & TA47 & 60.8 & -13.4 & 18.9 & & & & \\
\hline TA49 & 77.4 & -1.6 & 17.9 & & & & & TA47 bis & 35.0 & -3.6 & 5.7 & & & & \\
\hline TA50 & 74.3 & 2.4 & 15.4 & & & & & TA48 & 53.3 & -15.1 & 12.7 & & & & \\
\hline & & & & & & & & TA49 & 51.9 & -21.6 & 15.0 & & & & \\
\hline & & & & & & & & TA50 & 48.4 & -18.4 & 14.8 & & & & \\
\hline
\end{tabular}

\section{XRPD}

Semi-quantitative results obtained by XRPD analysis (Table 4) revealed a somewhat compositional homogeneity of ceramic body of samples, which is predominantly composed of quartz, followed by calcite, illite/muscovite and $\mathrm{K}$-feldspars as original minerals and gehlenite, diopside and hematite as new formed phases during firing. Plagioclase amounts account for original and new formed crystals.

\section{XRF}

The chemical analysis carried out by XRF technique allowed to investigate the concentration of major and traces oxides, reported in Table 5. In all the investigated TA samples, the most abundant oxide was $\mathrm{SiO}_{2}$, with mean value of $51.3 \%$ wt. The second predominant oxide was $\mathrm{Al}_{2} \mathrm{O}_{3}(x=16.1 \%$ $\mathrm{wt})$, followed by $\mathrm{CaO}(\bar{x}=13.2 \% \mathrm{wt})$ and $\mathrm{Fe}_{2} \mathrm{O}_{3 \text { tot }}(\bar{x}=6.6 \%$ wt).

As for trace elements, XRF results revealed the presence of $\mathrm{Sr}(236-500 \mu \mathrm{g} / \mathrm{g}), \mathrm{Zr}(117-186 \mu \mathrm{g} / \mathrm{g}), \mathrm{Rb}(81-127 \mu \mathrm{g} / \mathrm{g})$, $\mathrm{Y}(15-30 \mu \mathrm{g} / \mathrm{g})$ and $\mathrm{Nb}(7-18 \mu \mathrm{g} / \mathrm{g})$. 

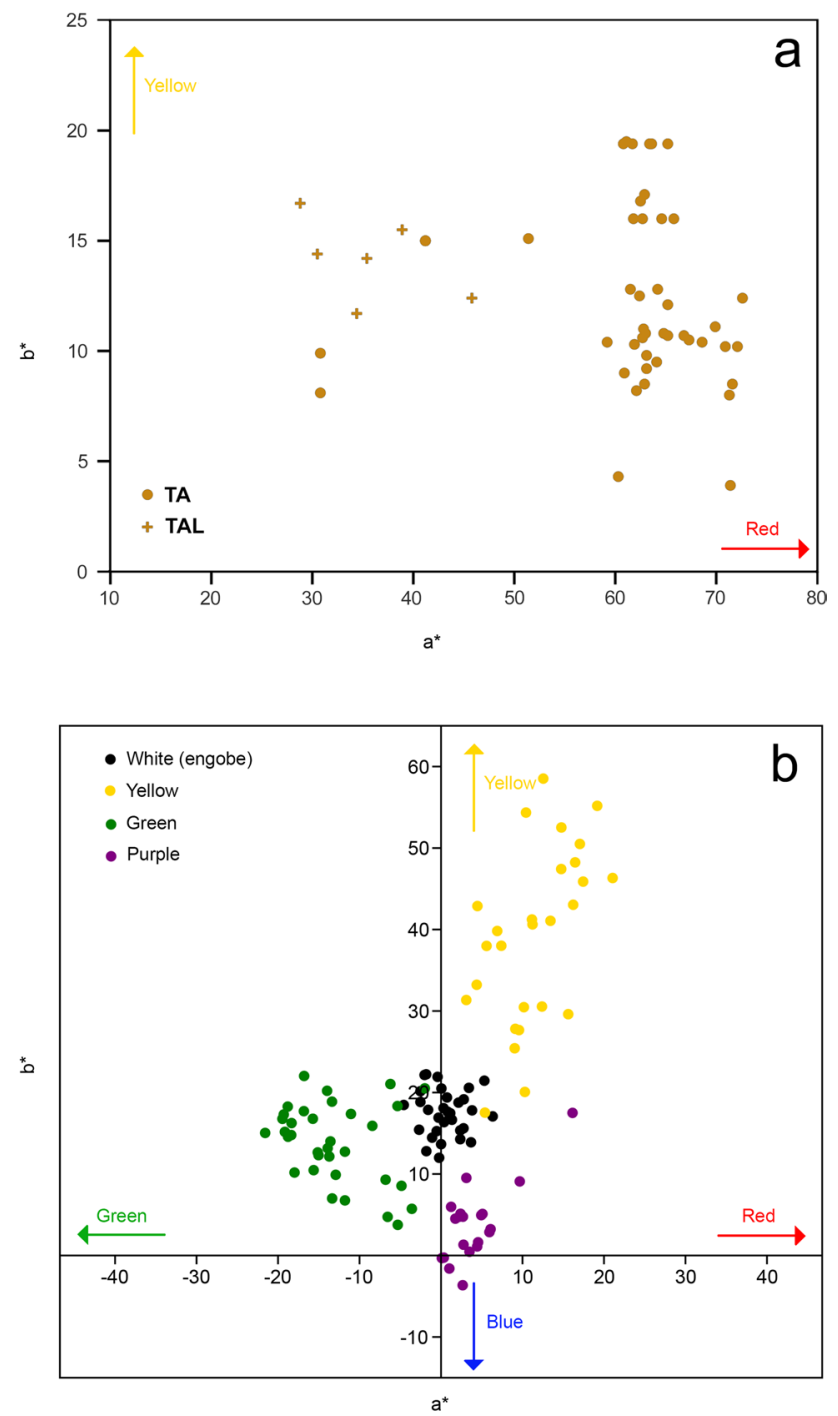

Fig. 5 Biplots of $a^{*}$ and $b^{*}$ values of CIEL*a*b* coordinates measured on cross-section (a) and on glaze (b)

\section{SEM-EDS}

SEM-EDS observations on the selected potsherd samples confirmed the low carbonates content of engobe and highlighted some glaze alteration ( $\mathrm{Pb}$ leaching and formation of $\mathrm{Pb}$ and $\mathrm{Ca}$ carbonates) on the outer surface and/or along fractures (Fig. 8).

The EDS results (Table 6) showed that all the TA samples were covered by a high lead glaze. The most abundant oxides are $\mathrm{PbO}$ (49.9-67.5\% wt), followed by $\mathrm{SiO}_{2}(24.5-37 \% \mathrm{wt})$ and $\mathrm{Al}_{2} \mathrm{O}_{3}(0.9-8.5 \% \mathrm{wt}$ ). Minor oxides (on average lower than 1 wt.\%) are $\mathrm{FeO}_{\text {tot }} \mathrm{Na}_{2} \mathrm{O}, \mathrm{K}_{2} \mathrm{O}, \mathrm{MgO}$ and $\mathrm{CaO}$.

In general, the colourless glaze appears free of chromophores elements, except for TA09 and TA49, which respectively contain minor concentrations $\mathrm{CuO}$ and $\mathrm{MnO}$ due to the proximity to coloured areas. The same is for yellow glazes which only in sample TA44 showed the presence of $\mathrm{CuO}$. In the other samples, the green and the purple are respectively due to the presence of $\mathrm{CuO}(2.2-14.8 \% \mathrm{wt})$ and $\mathrm{MnO}(0.8-1.9 \% \mathrm{wt})$.

High magnification BSD images of the body-glaze interface revealed a different reactivity between the glaze and the body compared to the engobe (Fig. 9). While the engobeglaze interface rarely shows the presence of a reaction zone with $\mathrm{Pb}-\mathrm{K}$ feldspar formation (Fig. 9a), this is typically present between the ceramic body and the glaze (Fig. 9b). Its thickness is about $20 \mu \mathrm{m}$ and aggregates of $\mathrm{Pb}-\mathrm{K}$ feldspar crystals are observed as liquidus phases, with the following mean weight percentages of major oxides (n. analysis $=35$ ): $\mathrm{SiO}_{2}=42.9 \pm 3.8 ; \mathrm{PbO}=29.5 \pm 7.6 ; \mathrm{Al}_{2} \mathrm{O}_{3}=14.4 \pm 5.1 ;$ $\mathrm{K}_{2} \mathrm{O}=4.8 \pm 3.0 ; \mathrm{CaO}=4.5 \pm 2.6 ; \mathrm{FeO}=1.7 \pm 0.9 ;$ $\mathrm{Na}_{2} \mathrm{O}=1.1 \pm 0.4$.

\section{Discussion}

\section{Ceramic body: clay provenance and processing}

Microscopic observation and the compositional data of the ceramic body allowed to give insight of the type of clay used and the processing to obtain the ceramic paste.

XRPD analysis of the ceramic body (Table 4) confirmed the mineralogical content observed under the polarising microscope and identified the presence of gehlenite, diopside, hematite, clay minerals and micas, which were not detectable by the POM.

Overall, the petrographic analysis defined three different fabrics types (KQ_k, KQKa_k, KQKa_kcp), characterised by carbonate-rich clay, with more or less fine unimodal texture (Table 3).

The use of carbonate-rich clay to prepare the paste for pottery and bricks is coherent with the clays available in the Tavoliere, where the marly clays of the Argille subappennine Fm contribute to the finer component of the alluvial sediments. However, the silt size of NPIs (Table 3), as well as the bulk chemical features (Tab. 5), infers fractionation of the clay.

The comparison of the chemical composition of the ceramic body of the plates with the bricks of Torre Alemanna and with the local clays of Argille subappennine Fm and alluvial clays (Gliozzo et al. 2018) showed significant correlations, as confirmed by PCA (Fig. 10).

Statistical data show the relative compositional homogeneity of TA ceramic body compared to the bricks (TAL) and also their difference. Furthermore, the chemical composition of bricks corresponds more closely to that of the alluvial deposits, than to that of the potsherds (Fig. 10). These aspects suggest that bricks were prepared using alluvial clays without a significant compositional modification, as 


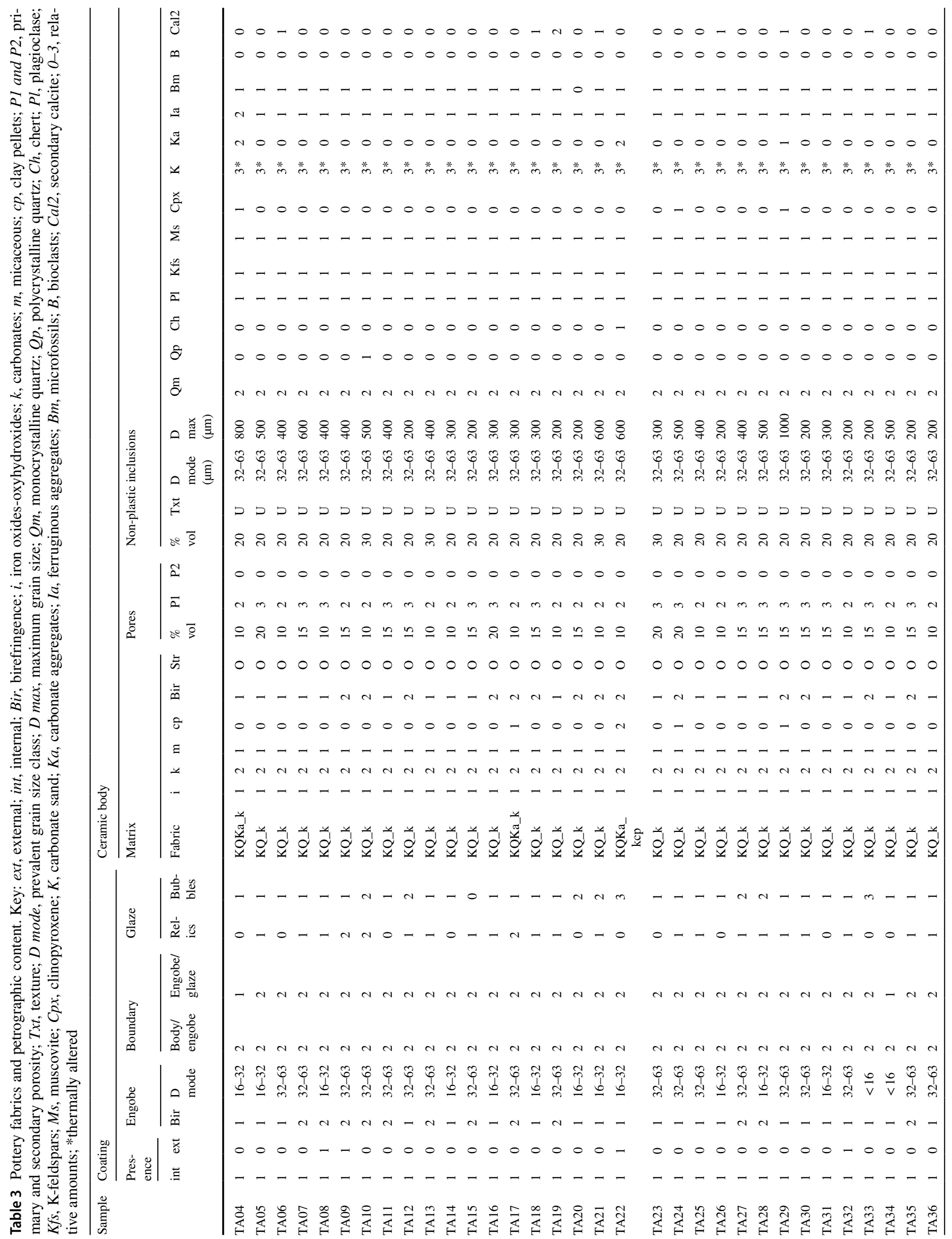




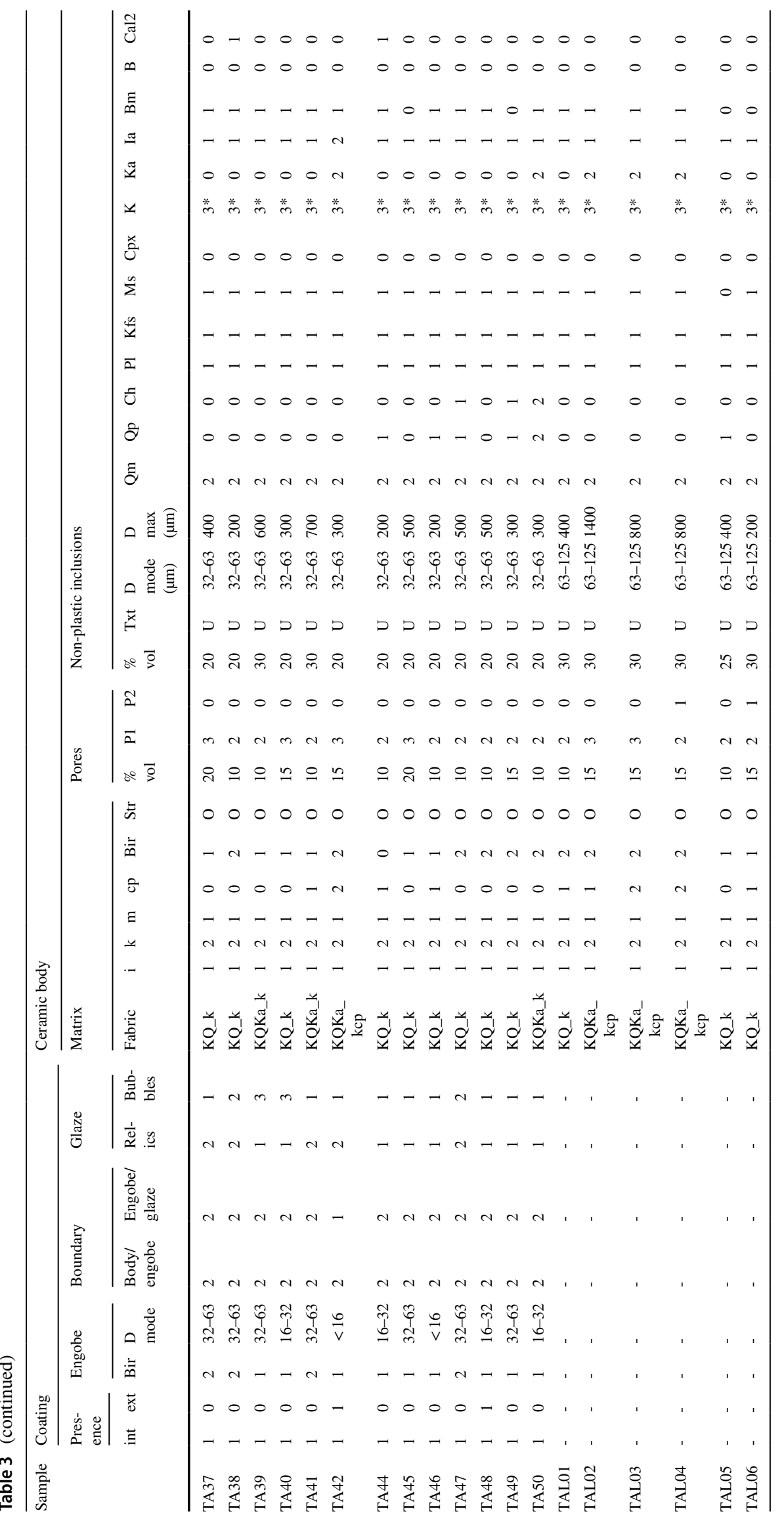



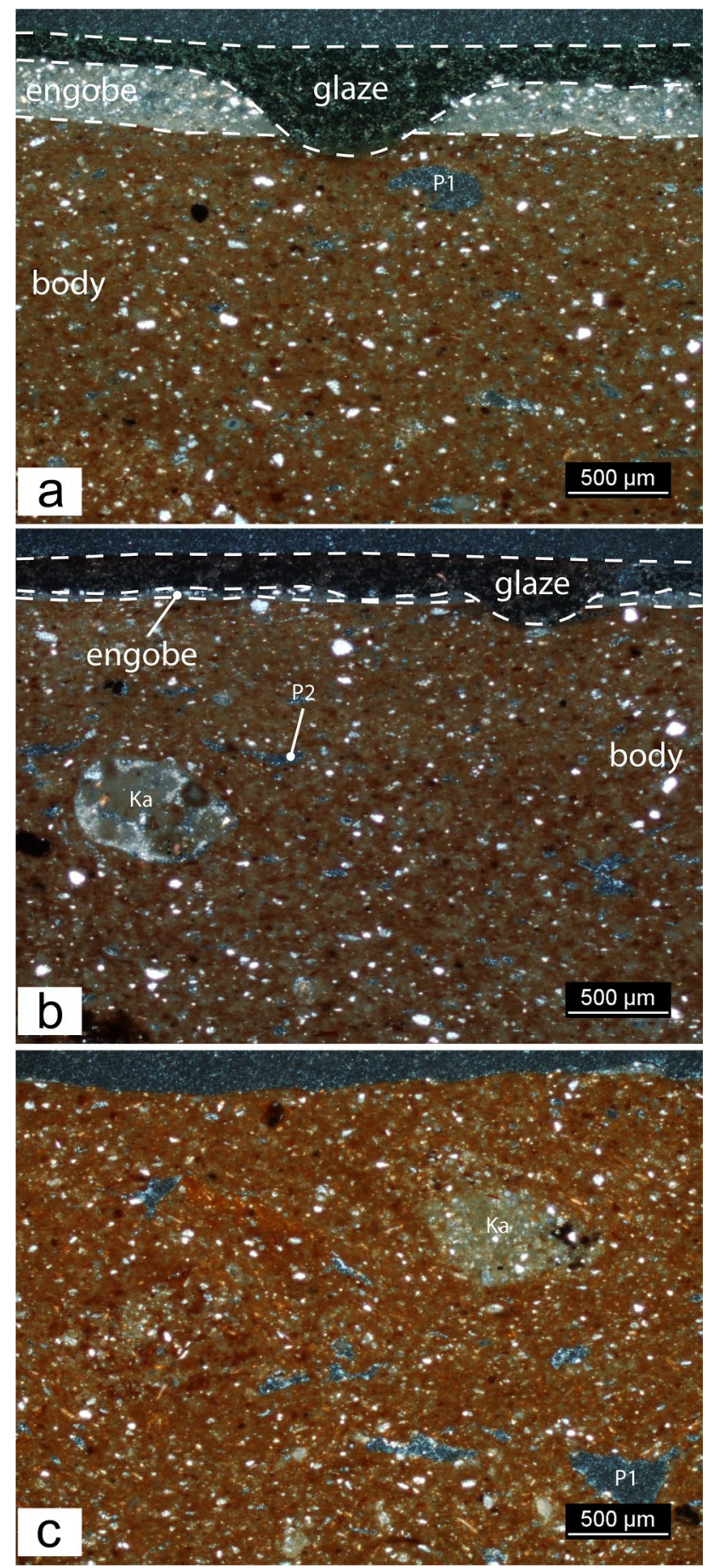

Fig. 6 POM microphotographs of the three different fabrics of the Torre Alemanna type ware: KQ_k (a), KQKa_k (b) and KQKa_kcp (c)

Fig. 11 seems to confirm. Conversely, a positive correlation $\left(R^{2}=0.73\right)$ between TA samples, Argille subappennine Fm and their relative clay fraction $(\varnothing<2 \mu \mathrm{m})$ shows that the composition of the ceramic body can be obtained from

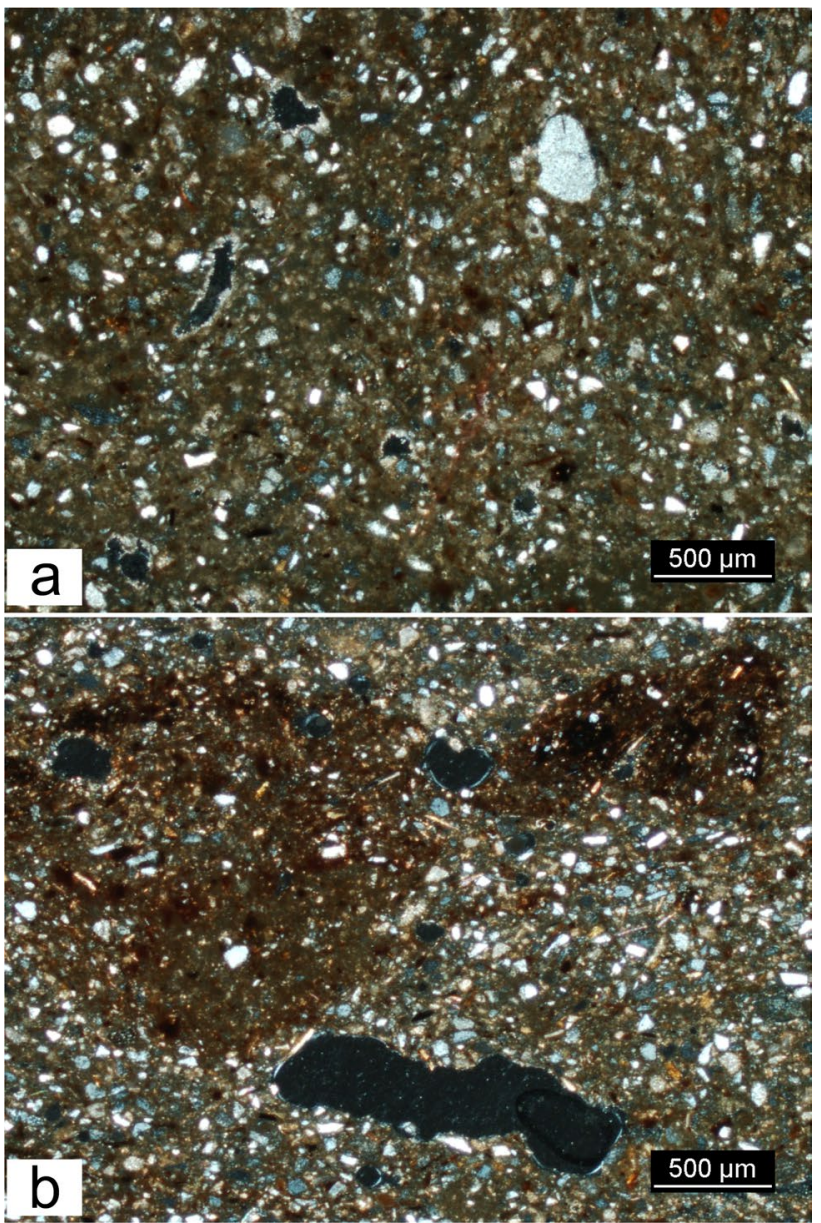

Fig. 7 POM microphotographs of the two different fabrics of the kiln bricks: KQ_k (a) and KQKa_kcp (b)

fractionation of unsorted Argille subappennine Fm or alluvial clays (Eramo 2020).

Other than chemical arguments for fractionation of the unsorted clay used for bricks, such petrographic features as finer grain size mode, lower fraction of NPIs, fine muscovite, traces of foraminifers and carbonate aggregates (calcrete) support this interpretation (Table 3). The rare presence of volcanic clinopyroxene proves to be a further indication of the use of local alluvial clays as raw material.

\section{Surface finishing and glazing}

POM and SEM-EDS analyses revealed a double coating as surface treatment, composed of a white engobe overlaid with a glaze of varying thickness, depending on the viscosity reached during firing (Figs. 6, 8, 9). The engobe has a fine and unimodal texture. Monocrystalline quartz constitutes NPIs in a carbonate poor and illitic matrix. Such white slurry cannot be obtained by fractionation of Argille subappennine 

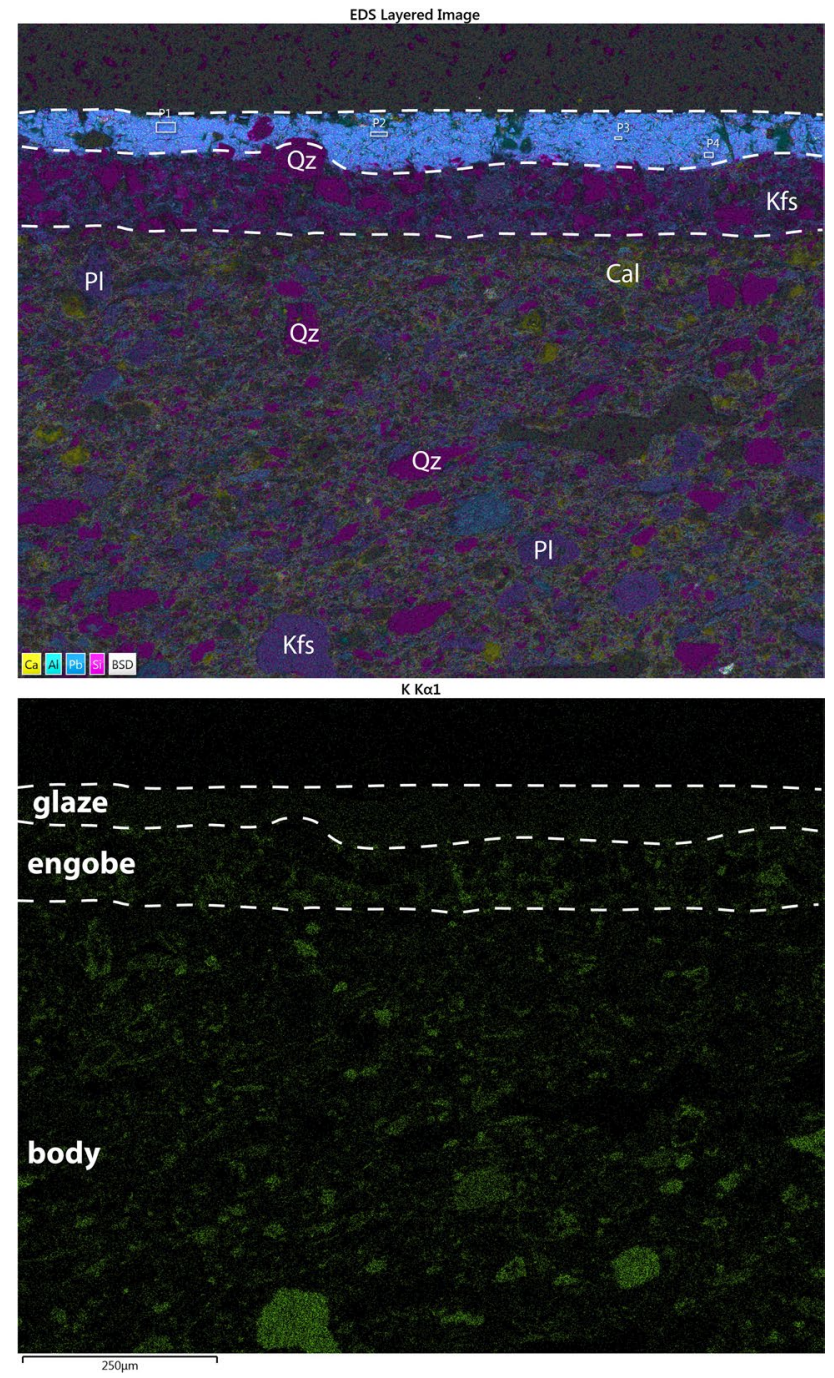

Fig. 8 Layered elemental map ( $\mathrm{Ca}, \mathrm{Al}, \mathrm{Pb}, \mathrm{Si})$ and $\mathrm{K}$ map obtained by SEM-EDS analysis of TA09, showing the composition and the microstructures of the coated ceramic body. Mineral abbreviations after Whitney and Evans (2010). Areas of purple dyed glaze (P1-P4) analysed with EDS

Fm or local alluvial clays and a primary clay must be considered raw material.

Following the macroscopic observation, it can be inferred that the engobe was applied to the green ceramic body by partial immersion of the plates in a white clay slurry and then incised.

The polychromatic decoration applied on the engobe was analysed by spectrophotometry, using CIEL*a*b* colour space (Table 2) and SEM-EDS (Table 6), to compare the colour characteristics and the chemical composition of the investigated areas. The coloured decoration was characterised by three main dyes, green, yellow-brown and purple, which partially filled the incised motifs on the inner surface of the plates. Colour coordinates show different degrees of dispersion (Fig. 5b). The coloured areas were often irregular, with clear to merging borders. Pigments used for pictorial decorations on incised surfaces are $\mathrm{Fe}$ oxyhydroxides for yellow brown, $\mathrm{MnO}$ for purple and $\mathrm{CuO}$ for green. Colour strains and glaze drippings are very common, suggesting lower viscosity of glaze in these domains and vertical position of plates during firing.

Poor sharpness in pictorial decoration, complete dissolution of oxides pigments in the glaze and negligible presence of crystalline compounds at the interface (Pradell and Molera 2020) suggest brush application of coloured pigments on raw unfired glaze (inglaze), as in "Splashed and Slip-incised types of Lead-glazed class" (Mason 1997).

SEM-EDS analysis revealed that the composition of glazes is characterised by significant presence of $\mathrm{PbO}$ $(50-68 \% \mathrm{wt})$, with an alkali content $\left(\mathrm{Na}_{2} \mathrm{O}+\mathrm{K}_{2} \mathrm{O}\right)$ normally lower than $2 \%$ wt and $\mathrm{Al}_{2} \mathrm{O}_{3}$ content between 3 and $8 \% \mathrm{wt}$ (Table 6). Relic quartz grains and minor amounts of alkali and alumina in glaze point to quartz-rich sand as component of the recipe for glaze preparation. $\mathrm{PbO}$ powder is considered probable source of lead. The results are consistent with the typical composition of transparent high lead type glazes (Tite et al. 1998).

\section{Firing}

The fabric and the mineralogical composition, as well as the chemical composition of the glaze, made it possible to understand the firing strategy adopted. Generally, for all the investigated samples, the POM analysis highlighted an oxidised homogeneous matrix (Table 3 ), medium-low birefringence and absence of shrinkage pores, then suggesting general oxidising firing conditions. The presence/absence of significant minerals revealed the equivalent firing temperatures (EFTs) (Tite 1995). The mineralogical composition was characterised by the absence (or traces) of the illite/muscovite and the presence of gehlenite, as metastable product of subsolidus reaction between phyllosilicates and carbonates (Maggetti 1982; Riccardi et al. 1999; Cultrone et al. 2001; Maritan et al. 2006; Allegretta et al. 2016; Maggetti et al. 2011; Gliozzo 2020). Thermally altered calcite grains are visible under POM (Fig. 6).

The mineralogical data (XRPD) suggest EFTs between 750 and $1000{ }^{\circ} \mathrm{C}$ (Table 4 ) of the ceramic body.

In the case of engobe, birefringence of the matrix and SEM-BSD images show a sintering degree between medium and high and, in some cases, an extended digestion by glaze (Fig. 6).

In order to estimate the melting temperature of the glaze, the mean values of $\mathrm{PbO}, \mathrm{SiO}_{2}$ and $\mathrm{Al}_{2} \mathrm{O}_{3}$ of the colourless portions of glaze analysed with EDS were normalised to $100 \%$ and plotted on the ternary phase diagram of $\mathrm{PbO}-$ $\mathrm{Al}_{2} \mathrm{O}_{3}-\mathrm{SiO}_{2}$ system (Fig. 12). The corresponding liquidus 
Table 4 Semi-quantitative mineral content by XRPD and estimated sintering degree and EFTs. Mineral abbreviations after Whitney and Evans (2010). Numbers indicate the abundance $(0$, absent; 1 , traces; from 2 to 4 , increasing presence)

\begin{tabular}{|c|c|c|c|c|c|c|c|c|c|c|}
\hline Sample & Qz & Pl & Kfs & $\mathrm{Cal}$ & Ill/Ms & Gh & Di & Hem & Sintering & $\mathrm{EFT}\left({ }^{\circ} \mathrm{C}\right)$ \\
\hline TA04 & 4 & 3 & 1 & 1 & 1 & 2 & 2 & 1 & Medium & $850-950$ \\
\hline TA05 & 4 & 3 & 1 & 1 & 1 & 2 & 2 & 1 & Medium & $850-950$ \\
\hline TA06 & 4 & 3 & 1 & 1 & 1 & 2 & 2 & 1 & Medium & $850-950$ \\
\hline TA07 & 4 & 3 & 1 & 1 & 1 & 2 & 2 & 1 & Medium & $850-950$ \\
\hline TA08 & 4 & 3 & 1 & 1 & 1 & 2 & 2 & 1 & Medium & $850-950$ \\
\hline TA09 & 4 & 3 & 1 & 1 & 1 & 2 & 2 & 1 & Medium & $850-950$ \\
\hline TA10 & 4 & 3 & 1 & 1 & 1 & 1 & 2 & 1 & Medium & $850-950$ \\
\hline TA11 & 4 & 3 & 1 & 1 & 1 & 2 & 2 & 1 & Medium & $850-950$ \\
\hline TA12 & 4 & 2 & 0 & 1 & 1 & 1 & 0 & 1 & Medium & $850-950$ \\
\hline TA13 & 4 & 2 & 0 & 1 & 1 & 2 & 1 & 1 & Medium & $800-950$ \\
\hline TA14 & 4 & 3 & 1 & 1 & 1 & 2 & 2 & 1 & Medium & $850-950$ \\
\hline TA15 & 4 & 2 & 1 & 2 & 1 & 2 & 2 & 1 & Low-medium & $750-850$ \\
\hline TA16 & 4 & 3 & 1 & 2 & 1 & 2 & 2 & 1 & Low-medium & $750-850$ \\
\hline TA17 & 4 & 2 & 0 & 1 & 1 & 2 & 1 & 1 & Medium & $800-950$ \\
\hline TA18 & 4 & 2 & 1 & 1 & 2 & 1 & 1 & 1 & Medium & $850-950$ \\
\hline TA19 & 4 & 2 & 2 & 2 & 1 & 1 & 1 & 1 & Low-medium & $750-850$ \\
\hline TA20 & 4 & 3 & 1 & 2 & 0 & 2 & 2 & 1 & Low-medium & $750-850$ \\
\hline TA21 & 4 & 2 & 1 & 2 & 2 & 2 & 0 & 1 & Low-medium & $750-850$ \\
\hline TA22 & 4 & 2 & 2 & 2 & 2 & 2 & 0 & 1 & Low-medium & $750-850$ \\
\hline TA23 & 4 & 3 & 1 & 0 & 1 & 2 & 2 & 1 & Medium-high & $850-1000$ \\
\hline TA24 & 4 & 2 & 0 & 2 & 2 & 2 & 1 & 1 & Low-medium & $750-850$ \\
\hline TA25 & 4 & 3 & 0 & 1 & 1 & 2 & 2 & 1 & Medium & $850-950$ \\
\hline TA26 & 4 & 2 & 1 & 2 & 1 & 2 & 2 & 1 & Low-medium & $750-850$ \\
\hline TA27 & 4 & 2 & 1 & 2 & 1 & 2 & 2 & 1 & Low-medium & $750-850$ \\
\hline TA28 & 4 & 3 & 0 & 1 & 0 & 2 & 2 & 1 & Medium & $850-950$ \\
\hline TA29 & 4 & 3 & 1 & 2 & 1 & 2 & 0 & 1 & Low-medium & $750-850$ \\
\hline TA30 & 4 & 2 & 2 & 2 & 1 & 2 & 1 & 1 & Low-medium & $750-850$ \\
\hline TA31 & 4 & 2 & 0 & 1 & 1 & 2 & 2 & 1 & Medium & $850-950$ \\
\hline TA32 & 4 & 2 & 0 & 2 & 1 & 2 & 1 & 1 & Low-medium & $750-850$ \\
\hline TA33 & 4 & 3 & 0 & 2 & 1 & 2 & 2 & 1 & Low-medium & $750-850$ \\
\hline TA34 & 4 & 3 & 1 & 2 & 1 & 2 & 2 & 1 & Low-medium & $750-850$ \\
\hline TA35 & 4 & 2 & 0 & 2 & 1 & 1 & 1 & 1 & Low-medium & $750-850$ \\
\hline TA36 & 4 & 3 & 1 & 2 & 1 & 2 & 2 & 1 & Low-medium & $750-850$ \\
\hline TA37 & 4 & 2 & 2 & 1 & 1 & 1 & 1 & 1 & Low-medium & $750-850$ \\
\hline TA38 & 4 & 2 & 0 & 2 & 1 & 2 & 2 & 1 & Low-medium & $750-850$ \\
\hline TA39 & 4 & 3 & 1 & 1 & 1 & 2 & 2 & 1 & Medium & $850-950$ \\
\hline TA40 & 4 & 2 & 0 & 2 & 2 & 1 & 1 & 1 & Low-medium & $750-850$ \\
\hline TA41 & 4 & 3 & 1 & 1 & 1 & 1 & 2 & 1 & Medium & $850-950$ \\
\hline TA42 & 4 & 3 & 1 & 2 & 1 & 2 & 2 & 1 & Low-medium & $750-850$ \\
\hline TA44 & 4 & 2 & 0 & 2 & 2 & 1 & 1 & 1 & Low-medium & $750-850$ \\
\hline TA45 & 4 & 3 & 1 & 0 & 1 & 2 & 2 & 1 & Medium-high & $850-1000$ \\
\hline TA46 & 4 & 3 & 1 & 0 & 1 & 2 & 2 & 1 & Medium-high & $850-1000$ \\
\hline TA47 & 4 & 2 & 1 & 2 & 1 & 2 & 2 & 1 & Low-medium & $750-850$ \\
\hline TA48 & 4 & 2 & 0 & 2 & 1 & 2 & 2 & 1 & Low-medium & $750-850$ \\
\hline TA49 & 4 & 2 & 0 & 2 & 1 & 2 & 2 & 1 & Low-medium & $750-850$ \\
\hline TA50 & 4 & 2 & 1 & 2 & 1 & 2 & 0 & 1 & Low-medium & $750-850$ \\
\hline
\end{tabular}

temperatures range from 780 to $950{ }^{\circ} \mathrm{C}$, although lower temperatures must be considered in portions of glaze where chromophore elements occur (i.e. Fe, $\mathrm{Cu}, \mathrm{Mn}$ ). Dispersed compositional points in the plot are also consequence of an incomplete maturation of the glaze. 
Table 5 Bulk chemical composition (XRF) of the ceramic bodies and bricks (oxides, $\%$ wt; trace elements, $\mu \mathrm{m} / \mathrm{g}$ ). Key: $\bar{x}$, mean; $s$, standard deviation; $c v$, coefficient of variation

\begin{tabular}{|c|c|c|c|c|c|c|c|c|c|c|c|c|c|c|c|c|c|}
\hline & Sample & $\mathrm{SiO}_{2}$ & $\mathrm{TiO}_{2}$ & $\mathrm{Al}_{2} \mathrm{O}_{3}$ & $\mathrm{Fe}_{2} \mathrm{O}_{3 \text { tot }}$ & $\mathrm{MnO}$ & $\mathrm{MgO}$ & $\mathrm{CaO}$ & $\mathrm{K}_{2} \mathrm{O}$ & $\mathrm{Na}_{2} \mathrm{O}$ & $\mathrm{P}_{2} \mathrm{O}_{5}$ & LOI & $\mathrm{Rb}$ & $\mathrm{Sr}$ & Y & $\mathrm{Zr}$ & $\mathrm{Nb}$ \\
\hline \multirow[t]{49}{*}{ Dishes } & TA04 & 51.69 & 0.78 & 16.01 & 6.65 & 0.11 & 3.28 & 13.96 & 2.82 & 0.91 & 0.21 & 3.58 & 115 & 302 & 25 & 158 & 16 \\
\hline & TA05 & 51.71 & 0.83 & 16.89 & 7.11 & 0.11 & 3.58 & 12.33 & 2.86 & 0.90 & 0.23 & 3.46 & 122 & 325 & 27 & 159 & 18 \\
\hline & TA06 & 49.26 & 0.74 & 15.15 & 6.17 & 0.10 & 3.72 & 15.19 & 2.51 & 0.87 & 0.19 & 6.09 & 111 & 333 & 25 & 159 & 15 \\
\hline & TA07 & 51.83 & 0.80 & 16.11 & 6.57 & 0.10 & 3.16 & 13.39 & 2.79 & 0.88 & 0.25 & 4.12 & 118 & 314 & 27 & 168 & 17 \\
\hline & TA08 & 51.78 & 0.83 & 17.00 & 7.18 & 0.11 & 3.67 & 12.20 & 2.92 & 0.79 & 0.23 & 3.29 & 126 & 306 & 26 & 150 & 17 \\
\hline & TA09 & 50.83 & 0.78 & 15.83 & 6.53 & 0.10 & 3.39 & 13.53 & 2.77 & 0.88 & 0.47 & 4.90 & 119 & 332 & 26 & 164 & 17 \\
\hline & TA10 & 51.09 & 0.80 & 16.44 & 6.95 & 0.10 & 3.55 & 13.57 & 2.78 & 0.80 & 0.22 & 3.69 & 121 & 322 & 26 & 152 & 17 \\
\hline & TA11 & 52.26 & 0.83 & 16.93 & 7.09 & 0.11 & 3.52 & 12.34 & 2.90 & 0.85 & 0.19 & 2.99 & 125 & 315 & 29 & 162 & 18 \\
\hline & TA12 & 51.20 & 0.80 & 16.26 & 6.71 & 0.11 & 3.10 & 13.50 & 2.86 & 0.81 & 0.19 & 4.47 & 119 & 307 & 26 & 160 & 17 \\
\hline & TA13 & 52.61 & 0.79 & 16.14 & 6.44 & 0.10 & 3.22 & 12.51 & 2.80 & 0.93 & 0.21 & 4.25 & 117 & 296 & 26 & 163 & 16 \\
\hline & TA14 & 51.37 & 0.81 & 16.54 & 6.93 & 0.10 & 3.59 & 13.13 & 2.84 & 0.82 & 0.22 & 3.65 & 122 & 324 & 28 & 160 & 17 \\
\hline & TA15 & 50.96 & 0.78 & 15.81 & 6.50 & 0.10 & 3.44 & 13.88 & 2.72 & 0.92 & 0.22 & 4.69 & 115 & 321 & 26 & 163 & 17 \\
\hline & TA16 & 52.09 & 0.82 & 16.85 & 7.05 & 0.10 & 3.56 & 12.21 & 2.88 & 0.84 & 0.23 & 3.37 & 124 & 313 & 27 & 158 & 18 \\
\hline & TA17 & 51.72 & 0.79 & 16.32 & 6.70 & 0.10 & 3.28 & 12.91 & 2.92 & 0.91 & 0.28 & 4.07 & 119 & 300 & 26 & 153 & 16 \\
\hline & TA18 & 52.94 & 0.80 & 15.96 & 6.62 & 0.10 & 3.16 & 13.24 & 2.82 & 0.84 & 0.28 & 3.24 & 119 & 313 & 27 & 172 & 17 \\
\hline & TA19 & 51.98 & 0.81 & 16.50 & 6.74 & 0.10 & 3.41 & 12.70 & 2.85 & 0.91 & 0.20 & 3.79 & 123 & 317 & 27 & 168 & 18 \\
\hline & TA20 & 49.77 & 0.77 & 15.95 & 6.57 & 0.10 & 3.48 & 13.33 & 2.89 & 0.80 & 0.23 & 6.10 & 121 & 327 & 28 & 162 & 17 \\
\hline & TA21 & 50.47 & 0.75 & 15.18 & 6.28 & 0.10 & 3.28 & 14.23 & 2.61 & 0.89 & 0.19 & 6.03 & 112 & 314 & 27 & 182 & 16 \\
\hline & TA22 & 52.37 & 0.78 & 16.10 & 6.66 & 0.10 & 3.21 & 12.40 & 3.17 & 0.95 & 0.25 & 4.00 & 118 & 314 & 27 & 160 & 17 \\
\hline & TA23 & 52.83 & 0.83 & 17.13 & 7.10 & 0.11 & 3.32 & 11.16 & 3.03 & 0.89 & 0.24 & 3.34 & 127 & 323 & 28 & 165 & 18 \\
\hline & TA24 & 51.45 & 0.81 & 16.68 & 6.94 & 0.10 & 3.23 & 12.52 & 2.92 & 0.80 & 0.20 & 4.34 & 124 & 312 & 28 & 164 & 18 \\
\hline & TA25 & 51.45 & 0.81 & 16.61 & 6.98 & 0.11 & 3.34 & 13.18 & 2.77 & 0.83 & 0.28 & 3.64 & 123 & 339 & 29 & 168 & 18 \\
\hline & TA26 & 51.44 & 0.79 & 16.07 & 6.63 & 0.10 & 3.39 & 12.91 & 2.83 & 0.83 & 0.21 & 4.81 & 120 & 316 & 28 & 166 & 17 \\
\hline & TA27 & 50.41 & 0.79 & 16.02 & 6.55 & 0.10 & 3.39 & 13.52 & 2.80 & 0.83 & 0.21 & 5.39 & 117 & 320 & 27 & 163 & 17 \\
\hline & TA28 & 52.41 & 0.80 & 16.37 & 6.72 & 0.10 & 3.45 & 12.73 & 2.75 & 0.94 & 0.20 & 3.54 & 122 & 323 & 30 & 179 & 17 \\
\hline & TA29 & 51.22 & 0.80 & 16.24 & 6.61 & 0.10 & 3.32 & 13.02 & 2.82 & 0.89 & 0.25 & 4.73 & 123 & 312 & 27 & 167 & 17 \\
\hline & TA30 & 51.09 & 0.77 & 15.87 & 6.52 & 0.10 & 3.19 & 13.26 & 2.79 & 0.88 & 0.30 & 5.22 & 118 & 315 & 29 & 179 & 17 \\
\hline & TA31 & 48.98 & 0.75 & 15.15 & 6.24 & 0.10 & 3.72 & 14.25 & 2.70 & 0.87 & 0.25 & 7.00 & 114 & 342 & 26 & 165 & 16 \\
\hline & TA32 & 50.72 & 0.78 & 16.01 & 6.55 & 0.10 & 3.06 & 13.68 & 2.80 & 0.87 & 0.22 & 5.21 & 120 & 326 & 29 & 171 & 17 \\
\hline & TA33 & 49.28 & 0.75 & 15.17 & 6.24 & 0.10 & 3.47 & 14.62 & 2.74 & 0.84 & 0.20 & 6.59 & 113 & 342 & 27 & 171 & 16 \\
\hline & TA34 & 49.39 & 0.74 & 15.18 & 6.17 & 0.10 & 3.78 & 14.98 & 2.51 & 0.86 & 0.18 & 6.09 & 113 & 355 & 28 & 172 & 16 \\
\hline & TA35 & 50.69 & 0.74 & 15.19 & 6.19 & 0.10 & 3.59 & 12.93 & 2.90 & 0.95 & 0.21 & 6.50 & 114 & 326 & 29 & 186 & 16 \\
\hline & TA36 & 50.85 & 0.76 & 15.51 & 6.32 & 0.10 & 3.38 & 14.13 & 2.61 & 0.89 & 0.21 & 5.24 & 114 & 337 & 28 & 172 & 17 \\
\hline & TA37 & 54.24 & 0.72 & 15.71 & 6.22 & 0.10 & 2.95 & 11.67 & 3.05 & 1.27 & 0.38 & 3.69 & 122 & 405 & 28 & 175 & 16 \\
\hline & TA38 & 51.66 & 0.79 & 16.15 & 6.65 & 0.10 & 3.07 & 12.89 & 2.86 & 0.84 & 0.47 & 4.53 & 121 & 313 & 29 & 163 & 17 \\
\hline & TA39 & 51.42 & 0.81 & 16.61 & 7.01 & 0.10 & 3.47 & 12.49 & 2.94 & 0.84 & 0.18 & 4.14 & 124 & 329 & 28 & 159 & 17 \\
\hline & TA40 & 49.44 & 0.70 & 14.46 & 5.90 & 0.10 & 3.47 & 13.66 & 3.06 & 0.85 & 0.28 & 8.06 & 101 & 335 & 26 & 181 & 15 \\
\hline & TA41 & 51.37 & 0.78 & 16.24 & 6.63 & 0.10 & 3.57 & 13.50 & 2.67 & 0.86 & 0.22 & 4.06 & 120 & 317 & 27 & 165 & 17 \\
\hline & TA42 & 51.38 & 0.77 & 15.71 & 6.37 & 0.10 & 2.38 & 14.33 & 2.66 & 0.80 & 0.15 & 5.36 & 118 & 301 & 27 & 155 & 17 \\
\hline & TA44 & 50.39 & 0.75 & 15.40 & 6.33 & 0.10 & 3.37 & 13.76 & 2.69 & 0.80 & 0.19 & 6.23 & 114 & 338 & 28 & 173 & 17 \\
\hline & TA45 & 51.95 & 0.81 & 16.49 & 6.85 & 0.11 & 3.37 & 12.91 & 2.74 & 0.83 & 0.24 & 3.69 & 122 & 341 & 29 & 178 & 18 \\
\hline & TA46 & 52.70 & 0.83 & 17.18 & 7.16 & 0.11 & 3.46 & 11.57 & 2.91 & 0.88 & 0.31 & 2.90 & 127 & 332 & 29 & 167 & 18 \\
\hline & TA47 & 51.27 & 0.81 & 16.61 & 6.89 & 0.10 & 3.48 & 12.40 & 2.92 & 0.81 & 0.21 & 4.49 & 124 & 312 & 29 & 162 & 18 \\
\hline & TA48 & 51.16 & 0.77 & 15.77 & 6.20 & 0.10 & 3.28 & 13.16 & 2.74 & 0.89 & 0.20 & 5.73 & 116 & 310 & 27 & 169 & 17 \\
\hline & TA49 & 51.05 & 0.76 & 15.60 & 6.12 & 0.10 & 3.19 & 13.37 & 2.72 & 0.88 & 0.22 & 6.00 & 116 & 318 & 28 & 173 & 17 \\
\hline & TA50 & 51.11 & 0.77 & 15.83 & 6.44 & 0.10 & 2.84 & 13.24 & 2.90 & 0.83 & 0.18 & 5.77 & 118 & 298 & 27 & 161 & 16 \\
\hline & $\bar{x}$ & 51.29 & 0.78 & 16.06 & 6.61 & 0.10 & 3.35 & 13.18 & 2.82 & 0.87 & 0.24 & 4.70 & 118.95 & 322.42 & 27.31 & 166.07 & 16.90 \\
\hline & $s$ & 1.06 & 0.03 & 0.61 & 0.32 & 0.00 & 0.25 & 0.85 & 0.13 & 0.07 & 0.06 & 1.21 & 5.01 & 18.13 & 1.19 & 8.11 & 0.78 \\
\hline & $c v$ & 0.02 & 0.04 & 0.04 & 0.05 & 0.04 & 0.07 & 0.06 & 0.05 & 0.08 & 0.27 & 0.26 & 0.04 & 0.06 & 0.04 & 0.05 & 0.05 \\
\hline
\end{tabular}


Table 5 (continued)

\begin{tabular}{|c|c|c|c|c|c|c|c|c|c|c|c|c|c|c|c|c|c|}
\hline & Sample & $\mathrm{SiO}_{2}$ & $\mathrm{TiO}_{2}$ & $\mathrm{Al}_{2} \mathrm{O}_{3}$ & $\mathrm{Fe}_{2} \mathrm{O}_{3 \text { tot }}$ & $\mathrm{MnO}$ & $\mathrm{MgO}$ & $\mathrm{CaO}$ & $\mathrm{K}_{2} \mathrm{O}$ & $\mathrm{Na}_{2} \mathrm{O}$ & $\mathrm{P}_{2} \mathrm{O}_{5}$ & LOI & $\mathrm{Rb}$ & $\mathrm{Sr}$ & $\mathrm{Y}$ & $\mathrm{Zr}$ & $\mathrm{Nb}$ \\
\hline \multirow[t]{9}{*}{ Bricks } & TAL01 & 42.28 & 0.47 & 9.76 & 3.73 & 0.09 & 1.74 & 20.05 & 2.36 & 0.53 & 0.26 & 18.73 & 104 & 260 & 15 & 125 & 8 \\
\hline & TAL02 & 41.56 & 0.50 & 10.25 & 3.90 & 0.08 & 1.86 & 19.09 & 3.99 & 0.94 & 0.13 & 17.71 & 92 & 500 & 17 & 139 & 8 \\
\hline & TAL03 & 45.96 & 0.57 & 11.90 & 4.27 & 0.09 & 2.12 & 16.06 & 2.68 & 0.63 & 0.19 & 15.54 & 112 & 344 & 21 & 167 & 9 \\
\hline & TAL04 & 46.36 & 0.57 & 11.88 & 4.28 & 0.09 & 2.13 & 16.30 & 2.48 & 0.61 & 0.19 & 15.11 & 103 & 325 & 20 & 160 & 9 \\
\hline & TAL05 & 45.67 & 0.56 & 11.61 & 4.48 & 0.09 & 2.05 & 17.25 & 2.16 & 0.61 & 0.23 & 15.30 & 81 & 236 & 15 & 117 & 7 \\
\hline & TAL06 & 45.02 & 0.57 & 11.24 & 4.82 & 0.10 & 1.95 & 17.44 & 2.18 & 0.66 & 0.22 & 15.80 & 110 & 311 & 21 & 163 & 10 \\
\hline & $\bar{x}$ & 44.48 & 0.54 & 11.11 & 4.25 & 0.09 & 1.98 & 17.70 & 2.64 & 0.66 & 0.20 & 16.37 & 100.33 & 329.33 & 18.17 & 145.17 & 8.50 \\
\hline & $s$ & 2.04 & 0.04 & 0.90 & 0.39 & 0.01 & 0.15 & 1.57 & 0.69 & 0.14 & 0.04 & 1.49 & 11.78 & 92.97 & 2.86 & 21.23 & 1.05 \\
\hline & $c v$ & 0.05 & 0.08 & 0.08 & 0.09 & 0.07 & 0.08 & 0.09 & 0.26 & 0.21 & 0.22 & 0.09 & 0.12 & 0.28 & 0.16 & 0.15 & 0.12 \\
\hline
\end{tabular}

Table 6 Chemical composition of coloured areas of glaze obtained by SEM-EDS. Key: $n$, number of measures; $\bar{x}$, mean; $s$, standard deviation

\begin{tabular}{|c|c|c|c|c|c|c|c|c|c|c|c|c|c|c|c|c|c|c|c|c|c|}
\hline \multirow[t]{2}{*}{ Sample } & \multirow[t]{2}{*}{ Colour } & \multicolumn{2}{|l|}{$\mathrm{SiO}_{2}$} & \multicolumn{2}{|l|}{$\mathrm{PbO}$} & \multicolumn{2}{|c|}{$\mathrm{Al}_{2} \mathrm{O}_{3}$} & \multicolumn{2}{|c|}{$\mathrm{Na}_{2} \mathrm{O}$} & \multicolumn{2}{|c|}{$\mathrm{K}_{2} \mathrm{O}$} & \multicolumn{2}{|c|}{$\mathrm{MgO}$} & \multicolumn{2}{|c|}{$\mathrm{CaO}$} & \multicolumn{2}{|c|}{$\mathrm{FeO}$} & \multicolumn{2}{|c|}{$\mathrm{MnO}$} & \multicolumn{2}{|l|}{$\mathrm{CuO}$} \\
\hline & & $x^{-}$ & $s$ & $x^{-}$ & $s$ & $x^{-}$ & $s$ & $\bar{x}$ & $s$ & $\bar{x}$ & $s$ & $x^{-}$ & $s$ & $x^{-}$ & $s$ & $x^{-}$ & $s$ & $x^{-}$ & $s$ & $\bar{x}$ & $s$ \\
\hline \multirow[t]{4}{*}{ TA09 } & Colourless (8) & 34.2 & 2.6 & 58.8 & 4.5 & 2.9 & 1.6 & 0.4 & 0.2 & 0.6 & 0.3 & 0.6 & 0.1 & 1.8 & 0.8 & 0.3 & 0.4 & - & - & 0.4 & 0.5 \\
\hline & Yellow (4) & 31.6 & 2.5 & 58.1 & 1.5 & 2.6 & 0.4 & 0.3 & 0.0 & 0.7 & 0.2 & 0.5 & 0.0 & 2.2 & 0.4 & 4.0 & 1.2 & - & - & - & - \\
\hline & Purple (4) & 35.4 & 1.9 & 55.4 & 2.5 & 3.5 & 1.1 & 0.4 & 0.1 & 0.7 & 0.3 & 0.6 & 0.0 & 1.5 & 0.1 & 0.4 & 0.1 & 1.9 & 0.4 & - & - \\
\hline & Green (4) & 30.5 & 1.2 & 63.8 & 1.3 & 1.5 & 0.4 & 0.2 & 0.1 & 0.3 & 0.1 & 0.4 & 0.0 & 1.0 & 0.1 & 0.1 & 0.2 & - & - & 2.2 & 0.4 \\
\hline \multirow[t]{3}{*}{ TA29 } & Colourless (3) & 31.9 & 0.7 & 56.8 & 3.2 & 8.5 & 2.5 & 0.2 & 0.2 & 0.7 & 0.2 & 0.7 & 0.0 & 1.2 & 0.1 & - & - & - & - & - & - \\
\hline & Yellow (3) & 28.2 & 1.5 & 60.3 & 2.1 & 6.0 & 1.5 & 0.5 & 0.1 & 0.5 & 0.1 & 0.6 & 0.1 & 1.1 & 0.1 & 2.7 & 0.4 & - & - & - & - \\
\hline & Green (3) & 27.3 & 0.3 & 60.6 & 1.3 & 5.0 & 0.5 & 0.9 & 0.1 & 0.4 & 0.1 & 0.5 & 0.0 & 1.2 & 0.2 & 1.1 & 0.3 & - & - & 3.2 & 0.5 \\
\hline \multirow[t]{4}{*}{ TA38 } & Colourless (3) & 26.7 & 1.7 & 62.3 & 2.4 & 4.4 & 0.8 & 0.5 & 0.0 & 0.6 & 0.1 & 0.5 & 0.1 & 1.2 & 0.2 & 3.8 & 3.1 & - & & - & \\
\hline & Yellow (3) & 26.5 & 0.7 & 60.3 & 0.6 & 5.4 & 0.6 & 0.5 & 0.0 & 0.6 & 0.1 & 0.5 & 0.0 & 1.4 & 0.2 & 4.8 & 0.7 & - & - & - & - \\
\hline & Purple (3) & 34.6 & 9.1 & 59.7 & 8.4 & 2.2 & 0.3 & 0.4 & 0.2 & 0.9 & 0.5 & 0.3 & 0.2 & 0.9 & 0.5 & 0.2 & 0.3 & 0.8 & 0.4 & - & \\
\hline & Green (3) & 27.8 & 1.6 & 58.6 & 0.7 & 6.1 & 0.2 & 1.2 & 0.1 & 0.8 & 0.2 & 0.6 & 0.1 & 1.7 & 0.4 & 0.7 & 0.4 & - & - & 2.6 & 0.4 \\
\hline \multirow[t]{2}{*}{ TA42 } & Colourless (3) & 37.0 & 1.3 & 49.9 & 2.8 & 7.9 & 0.6 & 0.6 & 0.1 & 1.2 & 0.3 & 0.6 & 0.1 & 1.8 & 1.6 & 1.0 & 0.7 & - & - & - & - \\
\hline & Green (3) & 32.2 & 1.5 & 56.4 & 1.3 & 5.2 & 1.6 & 1.0 & 0.2 & 0.6 & 0.1 & 0.5 & 0.1 & 1.0 & 0.4 & 0.6 & 0.2 & - & - & 2.6 & 0.1 \\
\hline \multirow[t]{3}{*}{ TA44 } & Colourless (5) & 32.5 & 1.4 & 61.4 & 1.4 & 3.6 & 0.8 & 0.2 & 0.1 & 0.4 & 0.1 & 0.3 & 0.1 & 1.4 & 0.2 & 0.2 & 0.2 & - & - & - & - \\
\hline & Yellow (5) & 31.2 & 1.5 & 59.2 & 1.4 & 3.7 & 1.1 & 0.2 & 0.1 & 0.5 & 0.1 & 0.3 & 0.0 & 1.2 & 0.1 & 3.5 & 0.9 & - & - & 0.3 & 0.6 \\
\hline & Green (5) & 24.4 & 0.6 & 67.4 & 0.4 & 7.8 & 0.3 & 0.1 & 0.1 & 0.6 & 0.1 & 0.7 & 0.0 & 0.9 & 0.1 & 2.4 & 1.3 & 0.9 & 0.0 & 14.8 & 1.0 \\
\hline \multirow[t]{4}{*}{ TA45 } & Colourless (4) & 32.8 & 1.5 & 56.7 & 0.5 & 4.8 & 1.2 & 0.2 & 0.0 & 0.7 & 0.0 & 0.3 & 0.0 & 3.4 & 0.2 & 1.1 & 0.2 & - & - & - & - \\
\hline & Yellow (3) & 34.1 & 1.4 & 59.7 & 1.3 & 2.3 & 0.4 & 0.2 & 0.0 & 0.5 & 0.1 & 0.6 & 0.1 & 0.7 & 0.1 & 2.0 & 0.4 & - & - & - & - \\
\hline & Green (4) & 31.2 & 0.4 & 60.7 & 0.5 & 2.4 & 0.4 & 0.0 & 0.0 & 0.4 & 0.0 & 0.4 & 0.1 & 1.1 & 0.2 & 0.5 & 0.1 & - & - & 3.3 & 0.3 \\
\hline & Purple (4) & 31.1 & 1.0 & 60.9 & 0.6 & 2.6 & 0.5 & 0.1 & 0.1 & 0.4 & 0.1 & 0.4 & 0.1 & 1.0 & 0.4 & 0.4 & 0.6 & 1.6 & 0.8 & 1.4 & 0.2 \\
\hline \multirow[t]{3}{*}{ TA46 } & Colourless (6) & 36.3 & 2.0 & 57.2 & 2.1 & 3.7 & 1.8 & 0.3 & 0.2 & 1.0 & 0.2 & 0.4 & 0.1 & 1.0 & 0.1 & 0.1 & 0.2 & 0.1 & 0.2 & - & - \\
\hline & Green (3) & 34.0 & 2.3 & 58.7 & 3.0 & 1.8 & 0.6 & 0.2 & 0.1 & 0.8 & 0.1 & 0.3 & 0.1 & 0.7 & 0.1 & 0.1 & 0.2 & - & - & 3.3 & 0.1 \\
\hline & Purple (3) & 31.1 & 0.9 & 64.7 & 0.4 & 0.9 & 0.6 & 0.1 & 0.0 & 0.3 & 0.0 & 0.2 & 0.0 & 0.8 & 0.0 & 0.1 & 0.1 & 1.8 & 0.0 & - & - \\
\hline
\end{tabular}

For a uniform glaze without mineral relics and gas bubbles, the viscosity of $10^{4}$ poise should be reached to mature the glaze. At the same firing temperature, lower liquidus temperatures for coloured glaze portions imply lower viscosity compared to colourless portions, and thus explain the colour glaze drippings and the partial digestion of the underlying engobe. Digestion of the engobe is less extended if compared to the ceramic body where the incisions occur
(Fig. 9). The preferential formation of $\mathrm{Pb}-\mathrm{K}$ feldspars in the reaction zone between glaze and ceramic body agrees with the lower solidus of $\mathrm{CaO}$ rich clays compared to $\mathrm{CaO}$ poor clays (Heimann 1989). The composition of $\mathrm{Pb}-\mathrm{K}$ feldspar microcrystals $(<5 \mu \mathrm{m})$ is similar to what measured by Maltoni et al. (2012) and Godet et al. (2019) for glazed pottery. The presence of quartz relics and bubbles points to subliquidus conditions comparable with those reported by 
Fig. 9 Details $(\mathbf{a}, \mathbf{b})$ of the SEM-BSE image of the glazebody interface of sample TA45 and elemental maps of $\mathrm{Pb}$ and $\mathrm{Ca}$. In the table, the semi-quantitative composition (EDS) of the $\mathrm{Pb}-\mathrm{K}$ feldspars in the frame $\mathrm{b}$ is reported
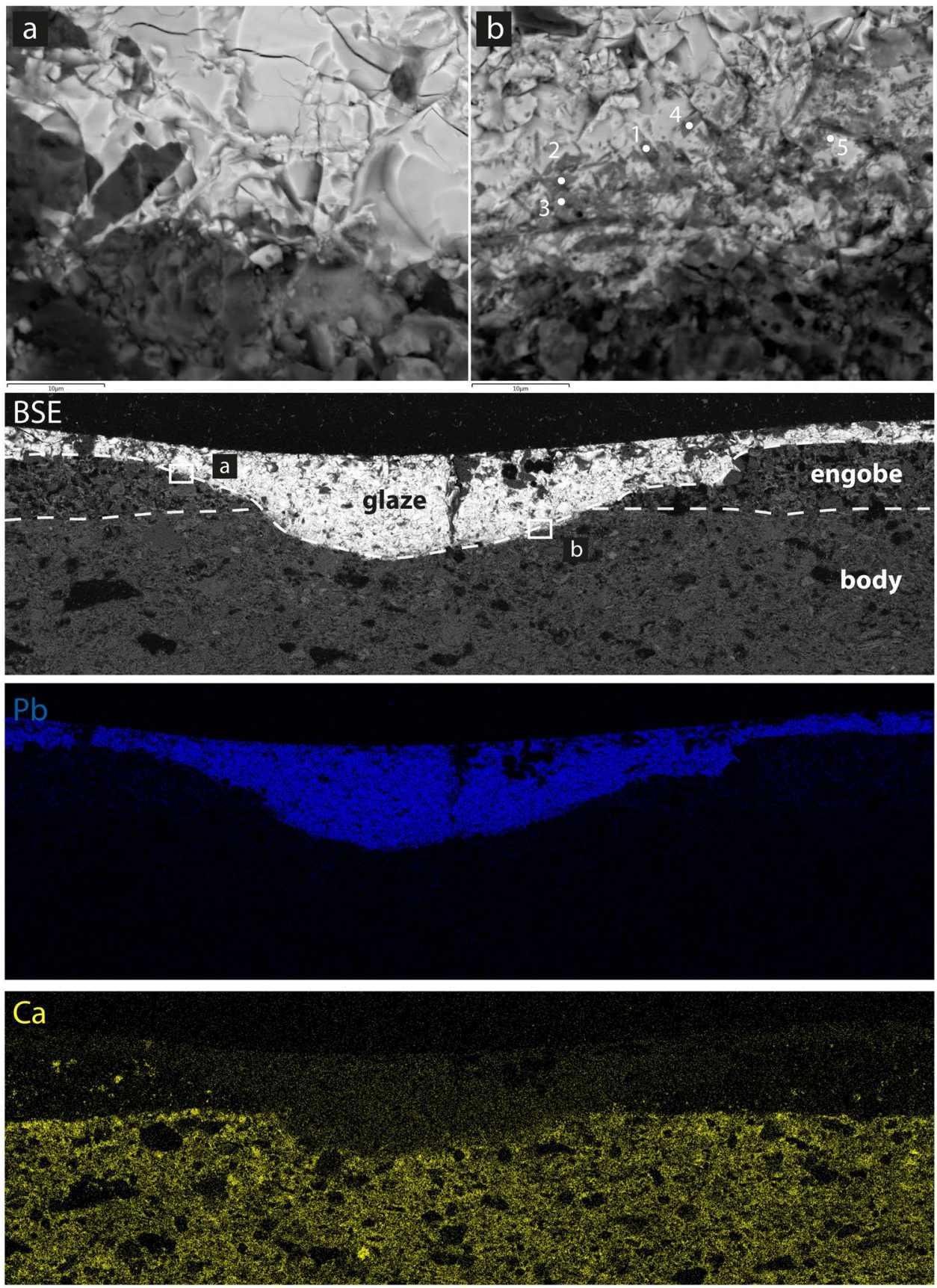

\begin{tabular}{|c|c|c|c|c|c|c|c|c|c|c|}
\hline Point & $\mathrm{SiO}_{2}$ & $\mathrm{Al}_{2} \mathrm{O}_{3}$ & $\mathrm{FeO}$ & $\mathrm{MnO}$ & $\mathrm{MgO}$ & $\mathrm{CaO}$ & $\mathrm{PbO}$ & $\mathrm{Na}_{2} \mathrm{O}$ & $\mathrm{K}_{2} \mathrm{O}$ & Total \\
\hline 1 & 44.1 & 14.2 & 1.4 & 0.4 & 0.9 & 3.1 & 29.3 & 1.0 & 5.5 & 100 \\
\hline 2 & 40.7 & 14.2 & 2.5 & 0.7 & 2.0 & 6.3 & 29.6 & 1.0 & 3.1 & 100 \\
\hline 3 & 37.9 & 10.0 & 2.7 & 1.0 & 2.9 & 6.8 & 35.7 & 1.1 & 1.8 & 100 \\
\hline 4 & 40.9 & 12.8 & 1.4 & 0.0 & 0.8 & 2.7 & 36.0 & 0.9 & 4.4 & 100 \\
\hline 5 & 40.5 & 10.1 & 1.7 & 0.6 & 0.7 & 3.0 & 40.1 & 0.8 & 2.5 & 100 \\
\hline
\end{tabular}


Molera et al. (2001) for low carbonate clays (K2) in contact with high lead glaze. Relatively higher viscosity associated with subliquidus conditions hinders chemical diffusion and bubble freeing, as well as body and engobe digestion. Moreover, the application of glaze by dipping, as observed on potsherds, is a further argument for reduced reactivity at glaze-engobe interface (Tite et al. 1998; Gualtieri et al. 2006). A comparison between the estimated temperatures for sintering of the ceramic body and maturing of glaze allows to discriminate between the double and single firings of the vessels. The overlap of the estimated temperature ranges for the ceramic body $\left(750-1000{ }^{\circ} \mathrm{C}\right)$ and the glaze $\left(780-950{ }^{\circ} \mathrm{C}\right.$ ) suggests a single firing, as also suggested by the coarse painted decorations. These temperature ranges match the maturing temperature range of high lead glaze $\left(800-1050{ }^{\circ} \mathrm{C}\right)$, as for Torre Alemanna, reported by Tite et al. (1998).

Experimental work on the reactivity of the glaze-body can be used as a reference. Gualtieri et al. (2006) report a glaze-body interface thickness of 20-30 $\mu \mathrm{m}$ for ceramic tests with a composition very similar to that of Torre Alemanna after a single firing. Interface thickness of $20 \mu \mathrm{m}$ was also observed by Ben Amara and Schvoerer (2006) in glazed ceramic test pieces fired once. However, the thickness of the glaze-body (or engobe) interface is a combination of several factors and increases with firing temperature and/or cooling time (Molera et al. 2001; Ben Amara et al. 2006). Setting aside the composition of the glaze and body and the firing temperatures, the cooling time can be considered short, if only the presence of $\mathrm{Pb}-\mathrm{K}$ feldspars at the glaze-Ca-rich body interface is considered, without the formation of wollastonite as a second liquidus phase, as in Ben Amara and Schvoerer (2006). Moreover, two firings in the same temperature range seem unjustifiable to obtain poorly defined underglaze designs.

\section{Conclusion}

The results of the archaeometric investigation showed that the ceramic body of the Torre Alemanna type was prepared by fractioning a carbonate-rich clay from local alluvial deposits. The decoration technique of the Torre Alemanna type production was based on the combination of sgraffito engraving with polychromatic coarse painting.

The surface treatment consisted of four consequential actions (Fig. 13) summarised as follows: after the fashioning and drying, the object was first covered by the engobe (action 1) and then the decorative patterns were incised to reveal the ceramic body beneath (action 2). A raw glaze was applied by dipping on the object surface (action 3 ), followed by the painted polychromatic decoration to highlight the decorative patterns (action 4).

A high lead glaze was used for all the vessels with some differences in composition and application. In the painted decorations, $\mathrm{Cu}, \mathrm{Mn}$ or Fe pigments were added to obtain green, purple or yellow, respectively. Analytical results and aesthetic arguments point to a single firing to sinter the ceramic body and to mature the glaze at the same time. It is worth noting that glazed sgraffito ceramics are generally considered to be obtained through a double firing, although petrographic, mineralogical and chemical evidence for such an interpretation is not always provided. In this work, an independent estimate of the temperatures reached by both the ceramic body and the glaze is proposed as an additional tool for the technological analysis of the artefacts. The results obtained here refer to this ceramic type and cannot be generalised. The growing number of researches on the glazed ceramic production in the Middle Ages allows a more and more articulated vision of the technological choices and of the circulation of typological models and manufactured articles throughout Italy and the Mediterranean area.

As for the Tavoliere plain, the results obtained showed a technological continuity with the past regarding the use of local carbonate-rich clay to produce fine pottery and defined the reference compositional group of Torre Alemanna type ware, already attested in various archaeological contexts in southern Italy. The ceramic body showed strong compositional homogeneity, denoting a standardised use of raw materials. 


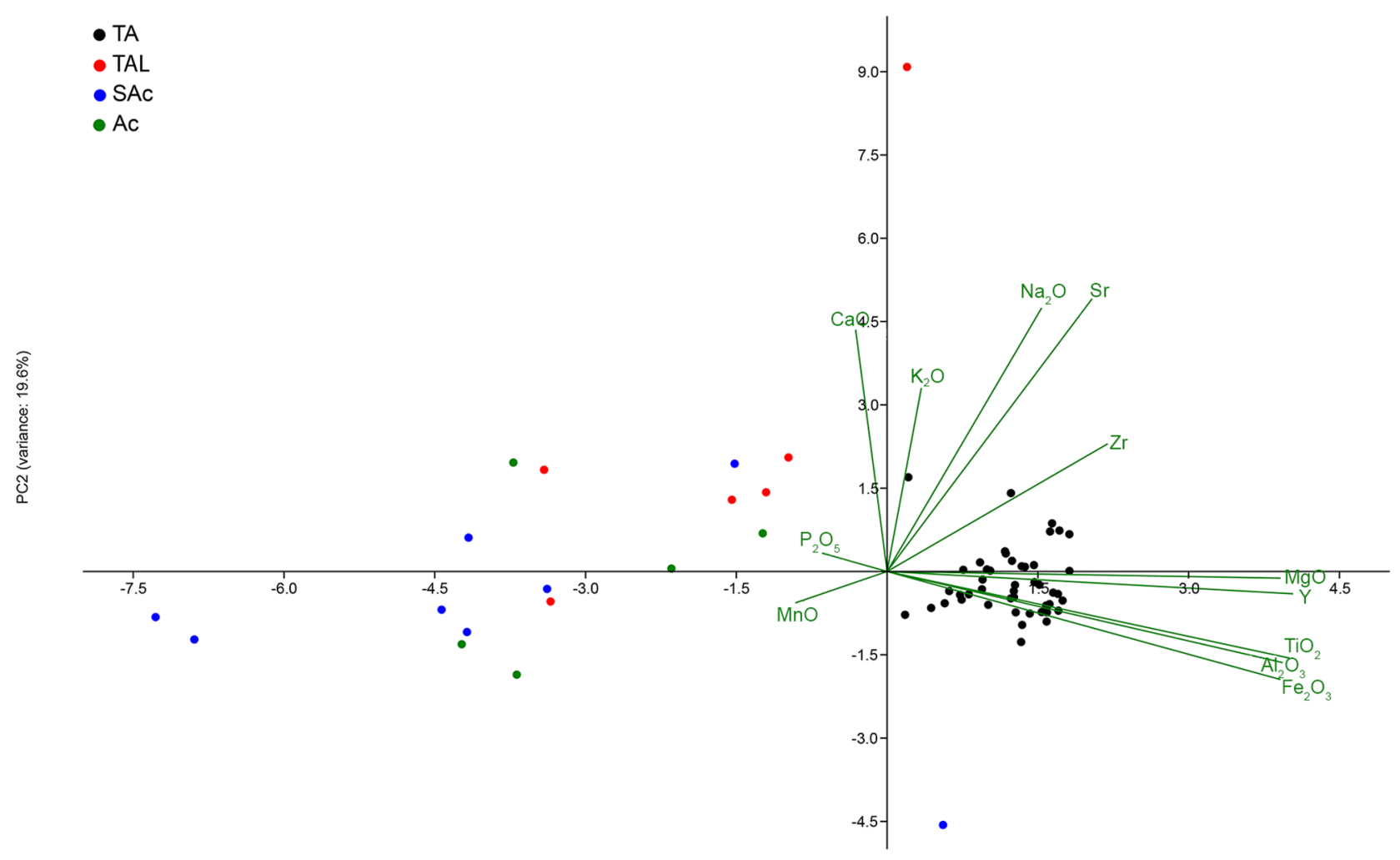

PC1 (variance: $42.4 \%$ )

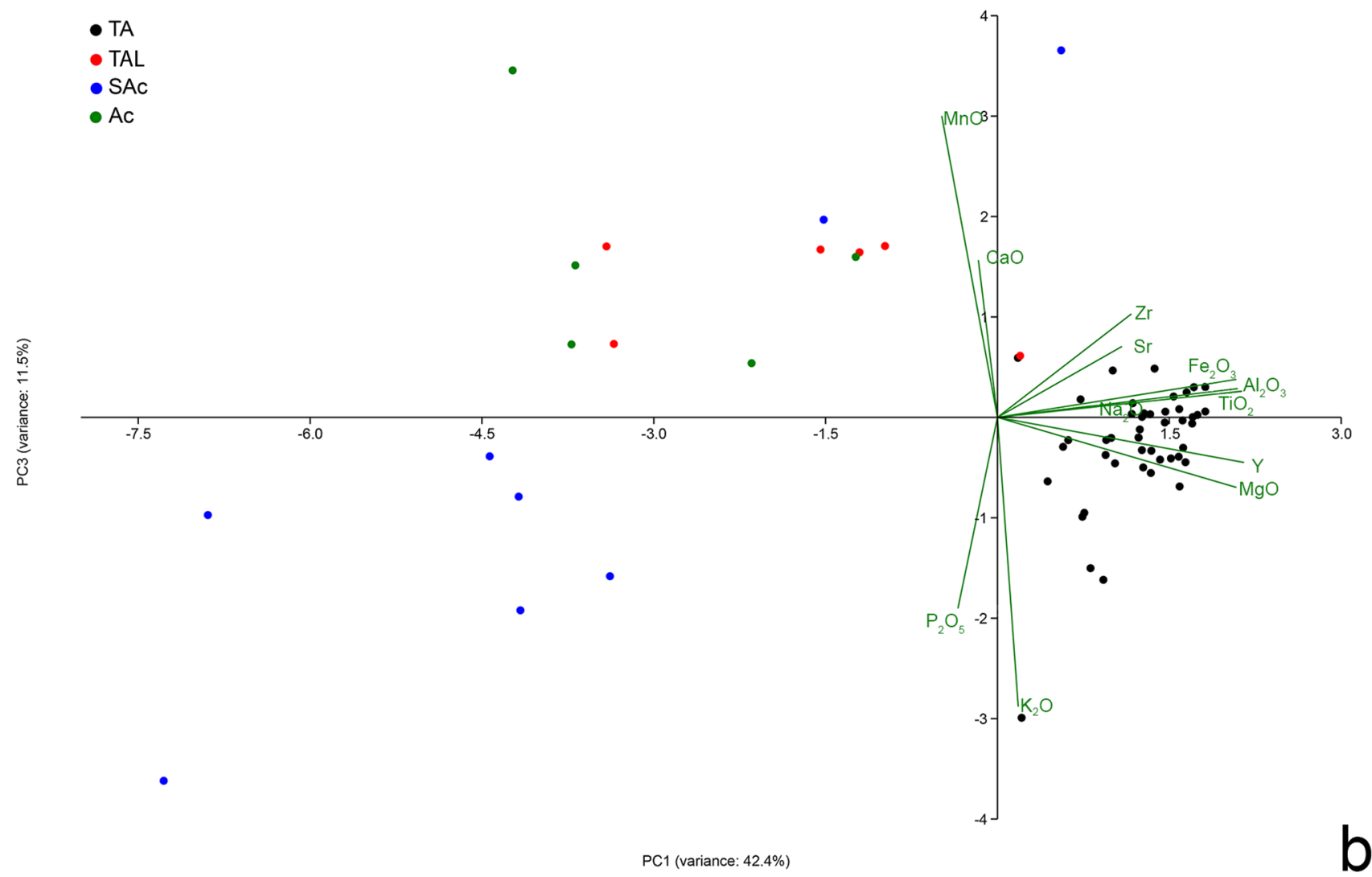


4Fig. 10 Biplots of PC1 vs PC2 (a) and PC1 vs PC3 (b) after principal component analysis of the bulk chemical data, including samples of Torre Alemanna type ware (TA), kiln bricks (TAL) and local clay sediments, both Argille subappennine Fm (SAc) and alluvial clays (Ac), presented in Gliozzo et al. (2018) improved the quality of the paper, as well as to Alba Rosa Scattaglia for the English revision. While reviewing this article, one of the authors (AB) passed away after a serious illness and we dedicate this to his memory.

Author contribution Giovanna Fioretti: conceptualisation, investigation, visualisation, writing. Giacomo Eramo: conceptualisation, meth-
Fig. 11 Scatter plot showing the $\mathrm{Al}_{2} \mathrm{O}_{3} / \mathrm{SiO}_{2}$ vs $\mathrm{MgO} / \mathrm{CaO}$ ratio in samples of Torre Alemanna type ware (TA) and bricks (TAL), compared with unsorted (total) and $<2 \mu \mathrm{m}$ fraction of Argille subappennine Fm (SAc) and alluvial clays (Ac) collected in the surroundings (Eramo et al. 2004, 2012, 2013)

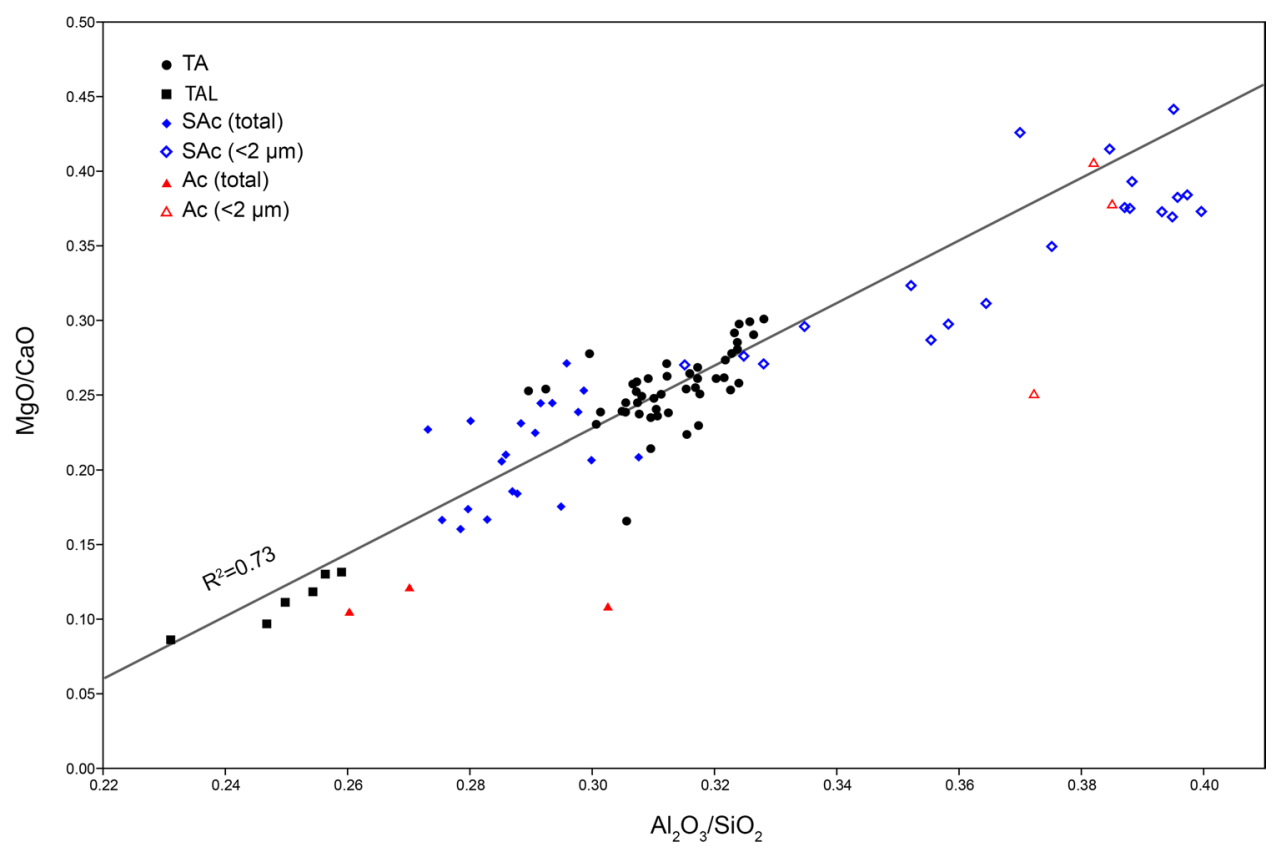

Acknowledgements The authors are very grateful to the two anonymous referees for their detailed and useful commentaries which odology, investigation, formal analysis, visualisation, resources, writing
Fig. 12 Ternary phase diagram of $\mathrm{PbO}-\mathrm{Al}_{2} \mathrm{O}_{3}-\mathrm{SiO}_{2}$ system (Chen et al. 2001, modified), indicating the normalised compositional points of the colourless glaze analysed by EDS (white circles) and the relative density map. Concentrations in $\%$ wt and temperatures in Kelvin

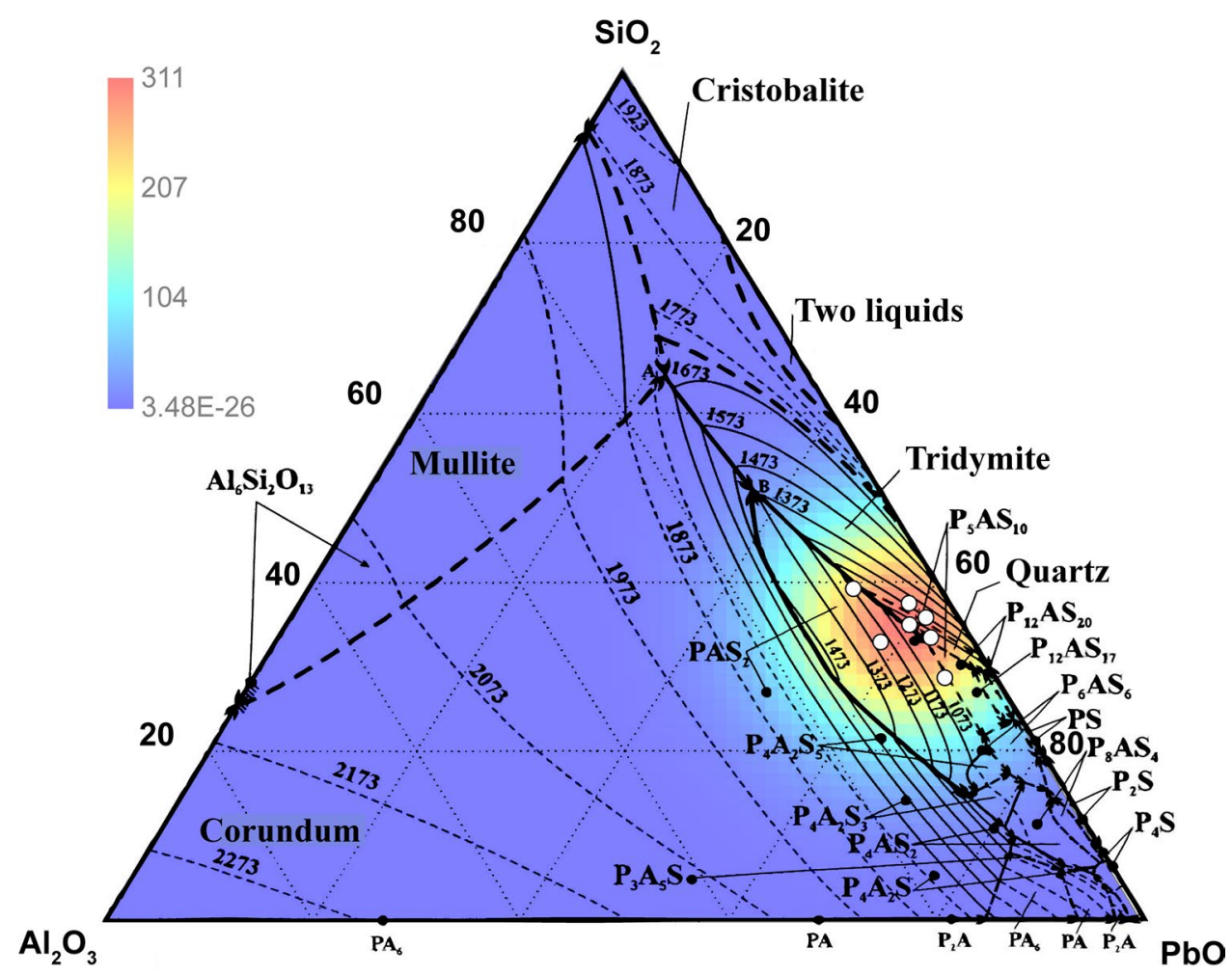


Surface treatment

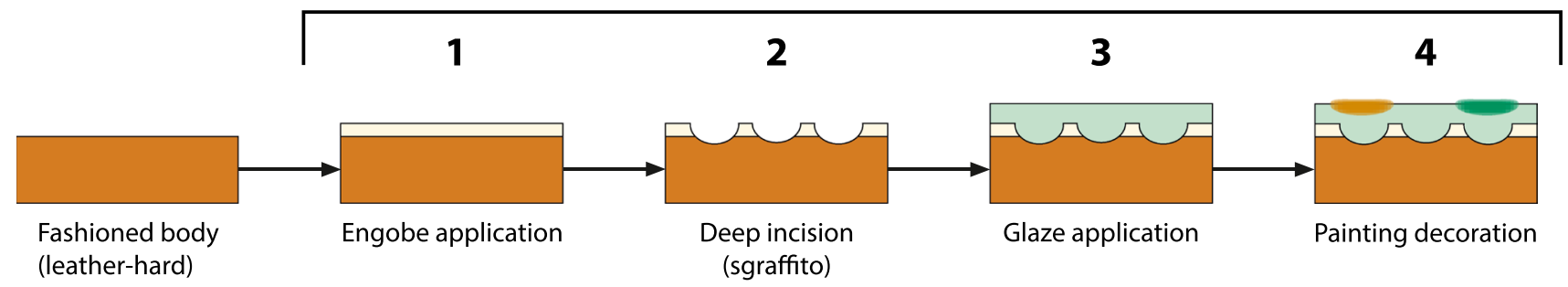

Fig. 13 The sequence of actions identified for the surface treatment before firing

(reviewing and editing), supervision. Alessandro Monno: investigation, writing. Austacio Busto: investigation, writing (original draft preparation). Rocco Laviano: resources, founding acquisition, editing.

Funding This work was possible thanks to the support of Carlo dell'Aquila and Filippo Vurro and to funding from Francesco Carofiglio (Consorzio Idria, Bari) and the research funds (ex 60\%) of the University of Bari Aldo Moro. The authors thank Pasquale Acquafredda and Nicola Mongelli for their technical support in SEM analysis. This research beneficed of instrumental upgrades of Potenziamento Strutturale PONa3-00369 of the University of Bari Aldo Moro titled "Laboratorio per lo Sviluppo Integrato delle Scienze e delle TEcnologie dei Materiali Avanzati e per dispositivi innovativi (SISTEMA)".

\section{Declarations}

Conflict of interest The authors declare no competing interests.

Open Access This article is licensed under a Creative Commons Attribution 4.0 International License, which permits use, sharing, adaptation, distribution and reproduction in any medium or format, as long as you give appropriate credit to the original author(s) and the source, provide a link to the Creative Commons licence, and indicate if changes were made. The images or other third party material in this article are included in the article's Creative Commons licence, unless indicated otherwise in a credit line to the material. If material is not included in the article's Creative Commons licence and your intended use is not permitted by statutory regulation or exceeds the permitted use, you will need to obtain permission directly from the copyright holder. To view a copy of this licence, visit http://creativecommons.org/licenses/by/4.0/.

\section{References}

Alaimo R, Bultrini G, Fragalà I et al (2004) Archaeometry of sicilian glazed pottery. Appl Phys A 79:221-227. https://doi.org/10. 1007/s00339-004-2523-3

Allegretta I, Pinto D, Eramo G (2016) Effects of grain size on the reactivity of limestone temper in a kaolinitic clay. Appl Clay Sci 126:223-234

Amato F, Fabbri B, Gualtieri S, Ruffini A, Valeri Moore A (2006) Sgraffito ceramics from Florentine area (XVI century): archaeometric characterization of paste and coating. In: Proceedings of the 34th International Symposium on Archaeometry 2004. 3-7 May 2004, Zaragoza, Spain, pp 365-370

Antonelli F, Ermeti AL, Lazzarini L, et al (2014) An archaeometric contribution to the characterization of $\mathrm{R}$ enaissance maiolica from $\mathrm{U}$ rbino and a comparison with coeval maiolica from $\mathrm{P}$ esaro (the $\mathrm{M}$ arches, central I taly). Archaeometry 56:784-804

Arthur P (2007) Byzantine and Turkish glazed ceramics in southern Apulia, Italy. In Çanak: Late antique and medieval pottery and tiles in Mediterranean archaeological contexts: Proceedings of the First International Symposium on Late Antique, Byzantine, Seljuk, and Ottoman Pottery and Tiles in Archaeological Context. Çanakkale, 1-3 June 2005, 239-254

Azzaroli A, Perno V, Radina B (1968) Note illustrative della Carte Geologica d'Italia, F 188 “Gravina di Puglia”, Serv Geol d'It, Roma

Balenzano F, Dell'Anna L, Di Pierro M (1977) Ricerche mineralogiche, chimiche e granulometriche su argille subappennine della Daunia (Puglia). Geologia Applicata e Idrogeologia 12:33-55

Ben Amara A, Schvoerer M (2006) Interactions between lead glazes and bodies: research on the mode of application of the glazing mixture. In: Proceedings of the 34th International Symposium on Archaeometry 2004. 3-7 May 2004, Zaragoza, Spain, 399-404

Busto A (2000) Il complesso masseriale di Torre Alemanna - Borgo Libertà (Cerignola -FG). In: Gravina A (ed) Atti XX convegno nazionale di studi sulla Preistoria, Protostoria e Storia della Daunia (San Severo - FG) 27-28 Novembre 1999, S. Severo, pp 3-22

Busto A (2008) Torre Alemanna: il contributo delle indagini archeologiche. In: Houben H, Toomaspoeg K (eds) L'Ordine Teutonico tra Mediterraneo e Baltico: incontri e scontri tra religioni, popoli e culture: Atti del Convegno internazionale (Bari-Lecce-Brindisi 14-16 settembre 2006), Congedo, Galatina, 289-343

Busto A (2012) La domus teutonica di Torre Alemanna (Cerignola): il contributo delle ultime ricerche archeologiche (dicembre 2007-gennaio 2008). In: Favia P, Houben H, Toomaspoeg K (eds) Federico II e i Cavalieri Teutonici in Capitanata: recenti ricerche storiche e archeologiche: Atti del Convegno Internazionale (Foggia-Lucera-Pietramontecorvino 10-13 giugno 2009), Congedo, Galatina, 541-559

Busto A, Ciminale D, dell'Aquila C (2001) Ceramiche da un sito dei Cavalieri Teutonici: Lo scavo di Torre Alemanna in Capitanata. In: Atti XXIII Convegno Internazionale della ceramica (Savona 26-28 maggio 2000), Centro Ligure per la Storia della Ceramica, Albisola, pp 325-336

Busto A, Pacilio G, Tenore A (2015) Le indagini archeologiche. In: dell'Aquila C (ed) Le ceramiche di Torre Alemanna: la graffita policroma e le altre tipologie dai cavalieri teutonici agli abati commendatari. Catalogo del Museo di Torre Alemanna, Città di Cerignola, Adda Editore, Bari, pp 33-48

Buttigieg E, Phillips S (2016) Islands and Military Orders, c. 1291-c. 1798. Routledge, London and New York

Caggiani MC, Barone G, de Ferri L, Laviano R, Mangone A, Mazzoleni P (2021) Raman and SEM-EDS insights into technological aspects of Medieval and Renaissance ceramics from Southern Italy. J Raman Spectrosc 52(1):186-198 
Caldara M, Capolongo D, Del Gaudio V, De Santis V, Pennetta L, Maiorano P, Simone O, Vitale G (2011) Note illustrative della Carta Geologica d'Italia alla scala 1:50.000, $\mathrm{F}^{\circ} 422$ "Cerignola", Istituto Superiore per la Protezione e la ricerca Ambientale, Roma

Caldara M, Pennetta L (1991) Pleistocenic buried abrasion platforms in southeastern Tavoliere (Apulia, South Italy). Il Quaternario 4:303-310

Caldara M, Pennetta L (1993) Nuovi dati per la conoscenza geologica e morfologica del Tavoliere di Puglia. Bonifica 8:25-42

Capelli C, Gavagnin S, Gardini A, Mannoni T (2002) Ingobbiate monocrome di produzione locale e di importazione a Genova (Palazzo Ducale) tra XI e XIII secolo: problemi tipologici ed archeometrici. In: Atti 34. Convegno internazionale della ceramica. All'insegna del giglio, Firenze, pp 1000-1011

Capelli C, Cabella R (2010) Archaeometric analyses of Mediterranean glazed cooking wares. ArcheoSciences Revue D'archéométrie 34:45-57. https://doi.org/10.4000/archeosciences. 2618

Carbosiero P, Magistrale F (1994) I materiali. Età medievale. Area urbana e territorio. In: Mazzei M (ed) Bovino. Studi per la storia della città antica. La collezione museale, Taranto, 248-266

Catalano IM, Genga A, Laganara C et al (2007) Lapis lazuli usage for blue decoration of polychrome painted glazed pottery: a recurrent technology during the Middle Ages in Apulia (Southern Italy). J Archaeol Sci 34:503-511

Chen S, Zhao B, Hayes PC, Jak E (2001) Experimental study of phase equilibria in the $\mathrm{PbO}-\mathrm{Al}_{2} \mathrm{O}_{3}-\mathrm{SiO}_{2}$ system. Metall Mater Trans B 32:997-1005

Clark RJ, Curri L, Henshaw GS, Laganara C (1997) Characterization of brown-black and blue pigments in glazed pottery fragments from castel fiorentino (Foggia, Italy) by Raman Microscopy, X-Ray Powder Diffractometry and X-Ray photoelectron spectroscopy. J Raman Spectrosc 28(2-3):05-109

Comodi P, Bernardi M, Bentivoglio A, Gatta GD, Zanazzi PF (2004) The production and technology of glazed ceramics from the middle ages, found in the saepinum territory (Italy): a multimethodic approach. Archaeometry 46(3):405-419

Cultrone G, Rodriguez-Navarro C, Sebastián E, Cazalla O, de la Torre MJ (2001) Carbonate and silicate phase reactions during ceramic firing. Eur J Mineral 13:621-634. https://doi.org/10.1127/09351221/2001/0013-0621

Davis JC (1986) Statistics and Data Analysis in Geology. John Wiley \& Sons Inc, New York

De Benedetto G, Acquafredda P, Masieri M et al (2004) Investigation on Roman lead glaze from Canosa: results of chemical analyses. Archaeometry 46:615-624

De Santis V, Caldara M, de Torres T, Ortiz JE (2010) Stratigraphic units of the Apulian Tavoliere plain (Southern Italy): chronology, correlation with marine isotope stages and implications regarding vertical movements. Sediment Geol 228:255-270

De Santis A, Mattei E, Montini I, Pelosi C (2012) A micro-raman and internal microstratigraphic study of ceramic sherds from the kilns of the Medici castle at Cafaggiolo. Archaeometry 54(1):114-128

De Santis V, Caldara M, Pennetta L (2013) The marine and alluvial terraces of Tavoliere di Puglia plain (southern Italy). J Maps 10(1):114-125. https://doi.org/10.1080/17445647.2013.861366

Dell'Anna L, Laviano R (1991) Mineralogical and chemical classification of Pleistocene clays from the Lucanian Basin (southern Italy) for the use in the Italian tile industry. Appl Clay Sci 6:233-243

dell'Aquila C (2015) La ceramica graffita policroma tipo Torre Alemanna e le altre graffite. In: dell'Aquila C (ed) Le ceramiche di Torre Alemanna: la graffita policroma e le altre tipologie dai cavalieri teutonici agli abati commendatari. Catalogo del Museo di Torre Alemanna, Città di Cerignola, Adda Editore, Bari, 49-108
dell'Aquila C, Laviano R, Vurro F (2006) Chemical and mineralogical investigations of majolicas (16th-19th centuries) from Laterza, southern Italy. In: Maggetti M, Messiga B (eds) Geomaterials in Cultural Heritage. Geological Society of London, Special Publication 257, 151-162

Doglioni C, Mongelli F, Pieri P (1994) The Puglia uplift (SE Italy): an anomaly in the foreland of the Apenninic subduction due to buckling of a thick continental lithosphere. Tectonics 13:1309-1321

Doglioni C, Harabaglia P, Martinelli G et al (1996) A geodynamic model of the Southern Apennines accretionary prism. Terra Nova 8:540-547

Dondi M, Fabbri B, Laviano R (1992) Characteristics of the clays utilized in the brick industry in Apulia and Basilicata (southern Italy). Mineral Petrogr Acta 35:181-191

Eramo G (2020) Ceramic technology: how to recognize clay processing. Archaeol Anthropol Sci 12:164. https://doi.org/10.1007/ s12520-020-01132-z

Eramo G, Laviano R, Muntoni IM, Volpe G (2004) Late Roman cooking pottery from the Tavoliere area (southern Italy): raw materials and technological aspects. J Cult Heritage 5:157-165. https:// doi.org/10.1016/j.culher.2003.05.002

Eramo G, Laviano R, Vurro F (2012) Indagine archeometrica dei laterizi e delle malte nei siti di Fiorentino e della fortezza di Lucera, In: Calò Mariani MS, Piponnier F, Beck P, Laganara C (eds) Fiorentino Ville Désertée Nel Contesto Della Capitanata Medievale (Ricerche 1982-1993), Collection Del' École Français De Rome, Roma, pp. 676-708

Eramo G, Giannossa LC, Rocco A, Mangone A, Graziano SF, Laviano R (2013) Oil lamps from the catacombs of Canosa (Apulia, fourth to sixth centuries $\mathrm{AD}$ ): technological features and typological imitation. Archaeometry 56:375-391. https://doi.org/10. 1111/arcm.12016

Eramo G, Mangone A (2019) Archaeometry of ceramic materials. PhysSci Rev 4https://doi.org/10.1515/psr-2018-0014

Fabbri B, Maldera R, Morandi N (1990) Composizione chimica di argille e reperti ceramici da Castelli, Deruta e Faenza. In: Atti del Convegno "Castelli e la maiolica cinquecentesca italiana". Pescara, Italy, 102-114

Favia P (2012) Produzioni e consumi ceramici nei contesti insediativi della Capitanata Medievale. In: Gelichi S (ed) Atti del IX Congresso Internazionale sulla Ceramica Medievale nel Mediterraneo (Venezia, Scuola Grande dei Carmini, Auditorium Santa Margherita, 23-27 novembre 2009), Borgo San Lorenzo. 480-486

Franzini M, Leoni L, Saitta M (1972) A simple method to evaluate the matrix effects in X-ray fluorescence analysis. X-Ray Spectrom 1:150-154. https://doi.org/10.1002/xrs.1300010406

Franzini M, Leoni L, Saitta M (1975) Revisione di una metodologia analitica per fluorescenza-X, basata sulla correzione completa degli effetti di matrice. Rend Soc Ital Mineral e Petrol 31(2):365-378

Gallicchio S, Moretti M, Spalluto L, Angelini S (2014) Geology of the middle and upper Pleistocene marine and continental terraces of the northern Tavoliere di Puglia plain (Apulia, southern Italy). J Maps 10:569-575. https://doi.org/10.1080/17445647. 2014.895436

Gardini A, Mannoni T (1995) Le tecniche empiriche dei vasai italiani. Dati archeologici e analisi scientifiche dei reperti. In: Actes du $5^{\text {ème }}$ Colloque sur la Céramique Médiévale en Mediterranée occidentale, $95-100$

Gelichi S (1993) La ceramica bizantina in Italia e la ceramica italiana nel Mediterraneo orientale tra XII e XIII secolo: stato degli studi e proposte di ricerca. In: Gelichi S (ed) La ceramica nel mondo bizantino tra XI e XV secolo ei sui rapporti con l'Italia. Atti del Seminario (Certosa di Pontignano 1991). All'Insegna del Giglio, Firenze, 9-46 
Giannossa LC, Acquaviva M, Laganara C et al (2014) Applications of a synergic analytical strategy to figure out technologies in medieval glazed pottery with "negative decoration" from Italy. Appl Phys A-Mater 116:1541-1552

Gliozzo E (2020) Ceramic technology. How to reconstruct the firing process. Archaeological and Anthropological Sciences 12:260. https://doi.org/10.1007/s12520-020-01133-y

Gliozzo E, Fortina C, Turbanti IM et al (2005) Cooking and Painted Ware from San Giusto (Lucera, Foggia): The Production Cycle, from the Supply of Raw Materials to the Commercialization of Products. Archaeometry 47:13-29. https://doi.org/10.1111/j. 1475-4754.2005.00185.x

Gliozzo E, Leone D, Origlia F, Turbanti Memmi I, Volpe G (2010) Archaeometric characterisation of coarse and painted fine ware from Posta Crusta (Foggia, Italy): technology and provenance. Archaeol Anthrop Sci 2:175-189

Gliozzo E, Turchiano M, Fantozzi PL, Romano AV (2018) Geosources for ceramic production and communication pathways: The exchange network and the scale of chemical representative differences. Appl Clay Sci 161:242-255. https://doi.org/10.1016/j. clay.2018.04.026

Godet M, Roisine G, Beauvoit E et al (2019) Multi-Scale Investigation of Body-Glaze Interface in Ancient Ceramics. Heritage 2:2480-2494

Goldthwaite RA (1989) The economic and social world of Italian Renaissance Maiolica. Renaiss Q 42:1-32

Gualtieri S, Ercolani G, Ruffini A, Venturi I (2006) Experimental tests for recognizing application technology and firing conditions of archaeological glazed ceramics. In: Proceedings of the 34th International Symposium on Archaeometry 2004. 3-7 May 2004, Zaragoza, Spain, 477-482

Hammer O, Harper DAT, Ryan PD (2001) PAST: PaleontologicalStatistics software package for education and data analysis. Palaeontol Electron 4:9

Heimann RB (1989) Assessing the technology of ancient pottery: the use of ceramic phase diagrams. Archeomaterials 3(2):123-148

Heimann RB, Maggetti M, Heiman G, Maggetti J (2014) Ancient and historical ceramics: materials, technology, art and culinary traditions

Heimann RB, Maggetti M (2019) The struggle between thermodynamics and kinetics: Phase evolution of ancient and historical ceramics. In: Artioli G, Oberti R (eds) The Contribution of Mineralogy to Cultural Heritage, 20. 233-281

Jacobacci, A., Malatesta, A., Martelli, G., Stampanoni, G., 1967. Note illustrative della Carta geologica d'Italia. Foglio 163-Lucera

Kingery WD (1993) Painterly maiolica of the Italian Renaissance. Technol Cult 34(1):28-48

Kingery WD, Vandiver PB (1986) Ceramic masterpieces: art, structure, technology. Free Press, New York

Laganara Fabiano C (2004) La ceramica medievale di Castel Fiorentino. Dallo scavo al museo. Adda Editore, Bari.

Laviano R, Muntoni IM (2006) Provenance and technology of Apulian Neolithic pottery. In: Maggetti M, Messiga B (eds) Geomaterials in Cultural Heritage. Geological Society of London, Special Publication 257:49-62

Leoni L, Saitta M (1976a) Determination of yttrium and niobium on standard silicate rocks by X-ray fluorescence analyses. X-Ray Spectrom 5:29-30. https://doi.org/10.1002/xrs.1300050107

Leoni L, Saitta M (1976b) X-ray fluorescence analysis of 29 trace elements in rock and mineral standards. Rendiconti Società Italiana Di Mineralogia e Petrografia 32(2):497-510

Levi ST, Amadori ML, Di Pillo M, Fratini F, Pecchioni E (1995) Archaeometric and archaeologic research on the pottery of Coppa Nevigata (FG-Italy): production and provenance. In: 8th CIMTEC-World Ceramic Congress and Forum on New Material, Techna, pp 423-432

Liverani G (1957) La maiolica italiana sino alla comparsa della porcellana europea, Electa. Milano

Mason RB (1997) Early mediaeval Iraqi lustre-painted and associated wares: typology in a multidisciplinary study. Iraq 59:15-61

Maggetti M (1982) Phase analysis and its significance for technology and origin. In: Olin JS, Franklin AD (eds) Archaeological Ceramics. Smithsonian Institution Press, Washington DC, pp $121-133$

Maggetti M, Neururer C, Ramseyer D (2011) Temperature evolution inside a pot during experimental surface (bonfire) firing. Appl Clay Sci 53:500-508

Maritan L, Nodari L, Mazzoli C, Milano A, Russo U (2006) Influence of firing conditions on ceramic products: experimental study on clay rich in organic matter. Appl Clay Sci 31:1-15. https://doi.org/10.1016/j.clay.2005.08.007

Matthew AJ, Woods AJ, Oliver C (1991) Spots before the eyes: new comparison charts for visual percentage estimation in archaeological material. In: Middleton A, Freestone I (eds) Recent developments in ceramic petrology. British Museum Occasional Paper 81. British Museum, London, 221-263

Maltoni S, Silvestri A, Maritan L, Molin G (2012) The Medieval lead-glazed pottery from Nogara (north-east Italy): a multimethodological study. Journal of Archaeological Science 39:2071-2078

Merla G, Ercoli A, Torre, D, 1969. Note Illustrative della carta Geologica d'Italia alla scala 1: 100000. Foglio 164: Foggia. Serv. Geol. Italia 22

Molera J, Pradell T, Salvadó N, Vendrell-Saz M (2001) Interactions between clay bodies and lead glazes. J Am Ceram Soc 84(5):1120-1128

Moretti M, Gallicchio S, Spalluto L, Ciaranfi N, Pieri P (2010) Evoluzione geologica del settore settentrionale del Tavoliere di Puglia (Italia meridionale) nel Pleistocene medio e superiore. Il Quat 23:181-198

Muntoni IM, Laviano R (2011) La ceramica neolitica in Puglia (Italia): stato dell'arte e prospettive della ricerca archeometrica. In: Alvarez-Hernandez A, Campione A, Otranto G (eds) Italia e Argentina. Itinerari di ricerca dall'antichità all'epoca della globalizzazione, Sodalitas 5, Bari, pp 49-67

Navarra MC (2008) Il complesso masseriale di Torre Alemanna (Foggia, XI-XVI sec.): analisi archeometriche di malte e laterizi. Bachelor thesis, Università di Bari Aldo Moro, unpublished

Pieri P, Sabato L, Tropeano M (1996) Significato geodinamico dei caratteri deposizionali e strutturali della Fossa Bradanica nel Pleistocene. Mem Soc Geol It 51:501-515

Pouchou J-L, Pichoir F (1991) Quantitative analysis of homogeneous or stratified microvolumes applying the model "PAP." In: Electron probe quantitation. Springer, 31-75

Pradell T, Molera J (2020) Ceramic technology. How to characterise ceramic glazes. Archaeological and Anthropological Sciences 12(8). https://doi.org/10.1007/s12520-020-01136-9

Pringle D (1982) Some more proto-maiolica from 'Athlit (Pilgrims' Castle) and a discussion of its distribution in the Levant. Levant 14(1):104-117

Randazzo MG (2019) The Evidence of Byzantine Sgraffito Wares in 12th-Century Sicily: A Case Study in Economic and Socio-cultural Connections between the Norman Kingdom of Sicily and Komnenian Greece? In: Transmitting and Circulating the Late Antique and Byzantine Worlds. Brill, 227-250

Riccardi MP, Messiga B, Duminuco P (1999) An approach to the dynamics of clay firing. Appl Clay Sci 15:393-409. https://doi. org/10.1016/S0169-1317(99)00032-0 
Ricchetti G, Ciaranfi N, Luperto Sinni E, Mongelli F, Pieri P (1988) Geodinamica ed evoluzione sedimentaria e tettonica dell'avampaese apulo. Memor Soc Geol Ital 41:57-82

Ricci C, Borgia I, Brunetti BG, Sgamellotti A, Fabbri B, Burla MC, Polidori G (2005) A Study on Late Medieval Transparent-Glazed Pottery and Archaic Majolica from Orvieto (central Italy). Archaeometry 47:557-570. https://doi.org/10.1111/j.1475-4754. 2005.00219.x

Ricciardi P, Amato F, Colomban P (2007) Raman spectroscopy as a tool for the non-destructive characterization of slips and glazes of a Sgraffito Renaissance production. In: Birò KT, Szilágyi V and Kreiter A (eds) Proceedings of the conference EMAC '07. 9th European Meeting on Ancient Ceramics. 24-27 October 2007, Hungarian National Museum, Budapest, Hungary, 217-222

Ruffini A, Gualtieri S, Fabbri B (2005) Comparison between Renaissance 'berettino' glazes from some ceramic centres in northern Italy. In: Kars $\mathrm{H}$ and Burke E (eds) Proceedings of the $33^{\text {rd }}$ International Symposium on Archaeometry, 22-26 April 2002, Amsterdam, Institute for Geo- and Bioarchaeology, Vrije Universiteit, Amsterdam, 249-52

Salvatore M (1980) Rinvenimenti ceramici sotto la cattedrale di Bari. In: Atti X Convegno Internazionale della Ceramica, Centro Ligure per la Storia della Ceramica, Albisola, pp 153-174

Tite MS (1991) Technological in investigations of Italian Renaissance ceramics. In: Wilson T (ed) Italian Renaissance pottery: papers written in association with a colloquium at the British Museum / the Trustees of the British Museum. British Museum Press, London, pp 280-285

Tite MS (1995) Firing temperature determination-how and why? In: Lindahl A, Stilborg O (eds) The aim of laboratory analyses of ceramics in archaeology. Kungliga vitterhets-, historie- och antikvitets akademien, Stockholm, Sweden, pp 37-42

Tite MS (2008) Ceramic production, provenance and use-a review. Archaeometry 50:216-231

Tite MS, Freestone I, Mason R, Molera J, Vendrell-Saz M, Wood N (1998) Lead Glazes in Antiquity-Methods of Production and
Reasons for Use. Archaeometry 40:241-260. https://doi.org/10. 1111/j.1475-4754.1998.tb00836.x

Troiano D, Verrocchio V (2001) Ceramiche quali indicatori di traffici commerciali fra Abruzzo, Molise e regioni limitrofe tra XV e XVII secolo. Archeologia Postmedievale 5:225-245

Tropeano M, Sabato L, Pieri P (2002) Filling and cannibalization of a foredeep: the Bradanic Trough, Southern Italy. Geological Society, London, Special Publications 191:55-79

Valenzano V (2016) I vasai di Montecorvino: aggiornamento sulla produzione di Protomaiolica nel foggiano. Storie [di] ceramiche 2. Maioliche "Arcaiche", 2:39-46.

Viti C, Borgia I, Brunetti B, Sgamellotti A, Mellini M (2003) Microtexture and microchemistry of glaze and pigments in Italian Renaissance pottery from Gubbio and Deruta. J Cult Herit 4(3):199-210

Waagé FO (1934) Preliminary report on the medieval pottery from Corinth I. The prototype of the achaic Italian majolica. Hesperia 3:129-139

Whitehouse D (1967) The medieval glazed pottery of Lazio. Papers of the British School at Rome 35:40-86

Whitehouse DM (1978) The origins of Italian maiolica. Archaeology 31(2q):42-49

Whitehouse DM (1986) Apulia. In: Atti del Terzo Congresso Internazionale "La ceramica medievale nel mediterraneo occidentale". Siena-Faenza, 8-12 ottobre 1984. All'Insegna del Giglio, Firenze, pp 573-586.

Whitney DL, Evans BW (2010) Abbreviations for names of rockforming minerals. Am Mineral 95:185-187. https://doi.org/10. 2138/am.2010.3371

Publisher's Note Springer Nature remains neutral with regard to jurisdictional claims in published maps and institutional affiliations. 